\title{
Regional controls on geomorphology, hydrology, and ecosystem integrity in the Orinoco Delta, Venezuela
}

\author{
Andrew G. Warne ${ }^{\mathrm{a}, *}$, Robert H. Meade ${ }^{\mathrm{b}}$, William A. White ${ }^{\mathrm{a}}$, Edgar H. Guevara ${ }^{\mathrm{a}}$, \\ James Gibeaut ${ }^{\mathrm{a}}$, Rebecca C. Smyth ${ }^{\mathrm{a}}$, Andres Aslan ${ }^{\mathrm{a}, 1}$, Thomas Tremblay ${ }^{\mathrm{a}}$ \\ ${ }^{\mathrm{a}}$ The University of Texas at Austin, Bureau of Economic Geology, University Station, Box X Austin, TX 78713-8924, USA \\ ${ }^{\mathrm{b}}$ US Geological Survey, MS 413, Box 25046, Federal Center, Denver, CO 80225-0046, USA
}

Received 7 March 2000; received in revised form 5 November 2000; accepted 19 January 2001

\begin{abstract}
Interacting river discharge, tidal oscillation, and tropical rainfall across the $22,000 \mathrm{~km}^{2}$ Orinoco delta plain support diverse fresh and brackish water ecosystems. To develop environmental baseline information for this largely unpopulated region, we evaluate major coastal plain, shallow marine, and river systems of northeastern South America, which serves to identify principal sources and controls of water and sediment flow into, through, and out of the Orinoco Delta. The regional analysis includes a summary of the geology, hydrodynamics, sediment dynamics, and geomorphic characteristics of the Orinoco drainage basin, river, and delta system. Because the Amazon River is a major source of sediment deposited along the Orinoco coast, we summarize Amazon water and sediment input to the northeastern South American littoral zone. We investigate sediment dynamics and geomorphology of the Guiana coast, where marine processes and Holocene history are similar to the Orinoco coast. Major factors controlling Orinoco Delta water and sediment dynamics include the pronounced annual flood discharge; the uneven distribution of water and sediment discharge across the delta plain; discharge of large volumes of water with low sediment concentrations through the Río Grande and Araguao distributaries; water and sediment dynamics associated with the Guayana littoral current along the northeastern South American coast; inflow of large volumes of Amazon sediment to the Orinoco coast; development of a fresh water plume seaward of Boca Grande; disruption of the Guayana Current by Trinidad, Boca de Serpientes, and Gulf of Paria; and the constriction at Boca de Serpientes. (C) 2002 Elsevier Science B.V. All rights reserved.
\end{abstract}

Keywords: Orinoco Delta; Orinoco River; Amazon; South America; Gulf of Paria; Mudcape; Mudbank; Fluid mud; Buoyant suspension layer; Hypopycnal plume

\footnotetext{
* Corresponding author. Current address: US Geological Survey, GSA Center 651 Federal Drive, Guaynabo, Puerto Rico.

E-mail address: agwarne@usgs.gov (A.G. Warne).

${ }^{1}$ Current address: Department of Physical and Environmental Science, Mesa State College, P.O. Box 2647, Grand Junction, CO 81501, USA.
}

\section{Introduction}

Interactions of river discharge, tidal oscillation, and tropical rainfall across the Orinoco delta plain support a variety of fresh and brackish water ecosystems that include unique and diverse plant and animal communities. More than $80 \%$ of the $22,000 \mathrm{~km}^{2}$ delta plain is perennially inundated, which greatly limits intentional burning and other anthropogenic alterations. More- 

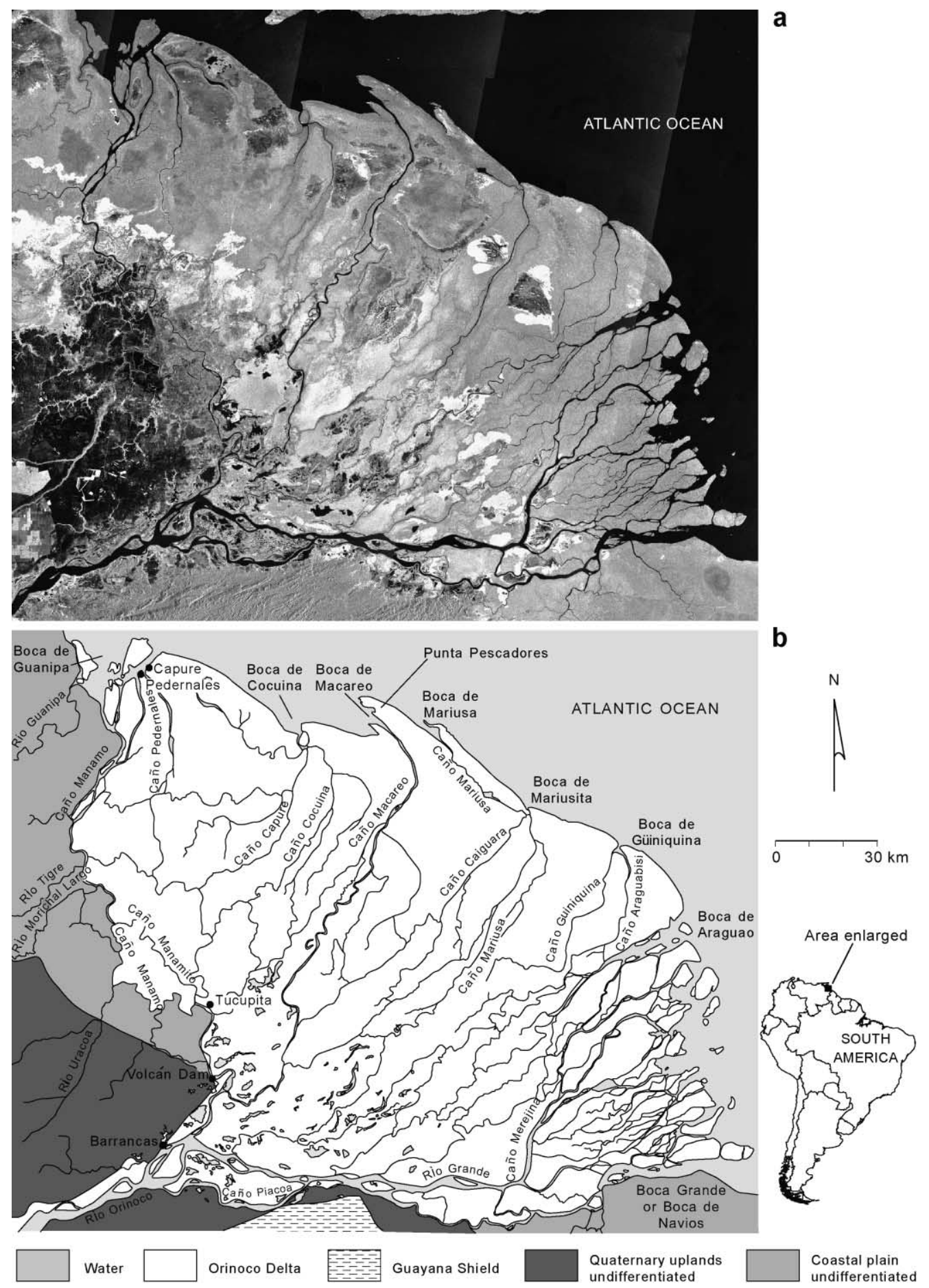

Fig. 1. (a) JERS (Radar inferometric) image of the Orinoco Delta. The composite image was acquired September to December 1995. (b) Geographic features of the Orinoco Delta. The mouths of major distributaries are referred to both as "Barra" (distributary mouth bar) and "Boca" (mouth). 
over, little has been done upstream along the Orinoco River to alter the natural cycle of water and sediment discharge to the delta. Hence, the ecosystem structure and composition of the Orinoco Delta retains most of its natural character.

The Orinoco Delta is a triangular to trapezoidal shaped depocenter with five to six major distributaries radiating from the apex to the coast (Fig. 1). River floods and marine tides (from $2.5 \mathrm{~m}$ at the coast to 0.6 $\mathrm{m}$ at the delta apex) maintain a network of channels (caños) throughout the low-gradient delta plain. Within this channel network are vast, shallow interdistributary basins, in which direct rainfall is a significant component of fresh water input. Near the
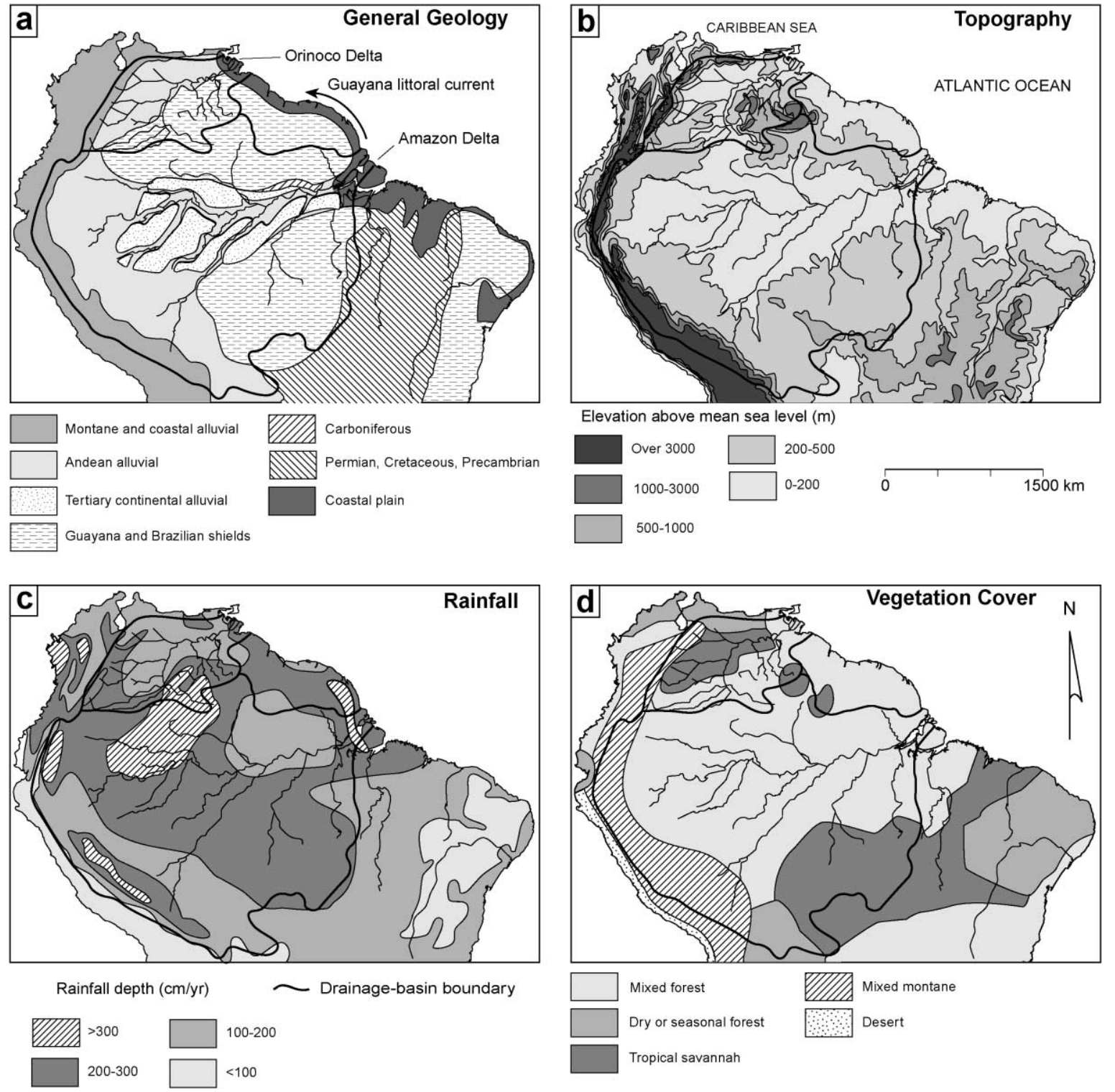

Fig. 2. (a) General surface geology, (b) topography, (c) rainfall distribution, and (d) vegetation cover across the Orinoco and Amazon drainage basins. Modified from Lewis et al. (1995). 
coast, many of the distributary channels deflect to the northwest under the influence of the northwest-directed Guayana littoral current. Broad, rounded promontories known as mudcapes form at the mouths of intermediate distributary channels, such as Caños Macareo and Mariusa, whereas estuaries develop at the mouths of major distributaries such as Boca Grande and Boca de Guanipa (Fig. 1). Nearly 85\% of the fresh water and river sediment is discharged through the Río Grande along the southern margin of the delta so that the northwestern delta is a more marine-influenced ecosystem complex. Amazon River sediments are transported northwestward along the northeastern South America coast by the Guayana littoral current $1600 \mathrm{~km}$ to the Orinoco coast (Fig. 2a); Amazon sediments comprise approximately $50 \%$ of the material deposited along the Orinoco coast and shelf (Eisma et al., 1978).

Deltas are transitional terrestrial-aqueous systems in which the landform configuration, water budget, and ecosystems reflect the balance of inputs and outputs associated with interacting climatic, upland, river, and marine processes. These transitional settings typically respond quickly and markedly to even modest changes in water and sediment inflow and throughflow. Human modifications commonly disrupt the balance of natural processes (typically fresh water and sediment supply) and thereby initiate a series of adverse impacts on delta ecosystems (Volker et al., 1993; DeLaune and Pezeshki, 1994; Bracho et al., 1998; Colonnello, 1998; Stanley and Warne, 1998).

To protect the diverse and unique Orinoco ecosystem complex from the potentially harmful effects of human activity, Petróleos de Venezuela sponsored an investigation of the entire delta system to identify and evaluate physical processes and process linkages that maintain the integrity of delta ecosystems (Warne et al., 1999). This baseline information is essential for developing design criteria that will minimize impacts associated with exploration and exploitation of hydrocarbon resources and other projects intended to enhance the economic and social welfare of the region.

This paper describes major regional processes that control the movement of water and sediment into and through the Orinoco Delta and along its coast. To do so, we integrate information generated by an extensive literature review, satellite image and historical aerial photograph analyses, and a series of delta expeditions. We briefly describe the geomorphic features and associated water and sediment dynamics of the Orinoco drainage basin and river system. Because the Amazon is a major contributor of sediment to the Orinoco Delta, we briefly describe the Amazon River and Delta system. Because the relatively well studied French Guiana, Suriname, and Guyana (Guiana) nearshore marine and coastal plain systems have many geomorphic features and processes that are similar to the Orinoco coast, we briefly describe the Guiana coastal region. We then describe major hydrologic and geomorphic features and processes of the Orinoco Delta. Finally, we summarize major regional processes controlling Orinoco Delta ecosystem integrity.

\section{Orinoco drainage basin and river}

The Orinoco basin covers about $1.1 \times 10^{6} \mathrm{~km}^{2}$ of northern South America (Figs. 2a and 3; Table 1). The Orinoco drainage basin consists of about 35\% Guayana Shield, 15\% Andes and Coastal mountain ranges, and 50\% Llanos (Fig. 3). The Guayana Shield is composed largely of felsic to intermediate plutonic rocks and gneisses that are commonly overlain by massive quartzites (Gibbs and Barron, 1983; Corporación Venezolana de Guayana (CVG), 1991a-f). Maximum relief on the elevated shield is on the order of $3000 \mathrm{~m}$ (Fig. 2b), but the majority of the shield is low relief, has deeply weathered soils, and is densely vegetated.

Mountainous fold and thrust terrains form the western and northern margin of the drainage basin (Figs. 2a,b and 3). The predominant lithologies exposed in the fold and thrust terrains are shale, limestone, sandstone, and conglomerate (and their metamorphic equivalents), as well as felsic and mafic plutonic rocks. Steep slopes and sharp peaks with maximum relief of $5000 \mathrm{~m}$, and active alpine glaciation at higher elevations, characterize these young, mountainous terrains. The Andean Orogeny, which began in the late Oligocene and peaked in the Pliocene, is a major influence in the development of the Amazon and Orinoco River systems.

The Llanos region is a foreland basin that is filled with sediments derived from the rising Andean terrain to the west. As the Spanish name implies, vast grassy 


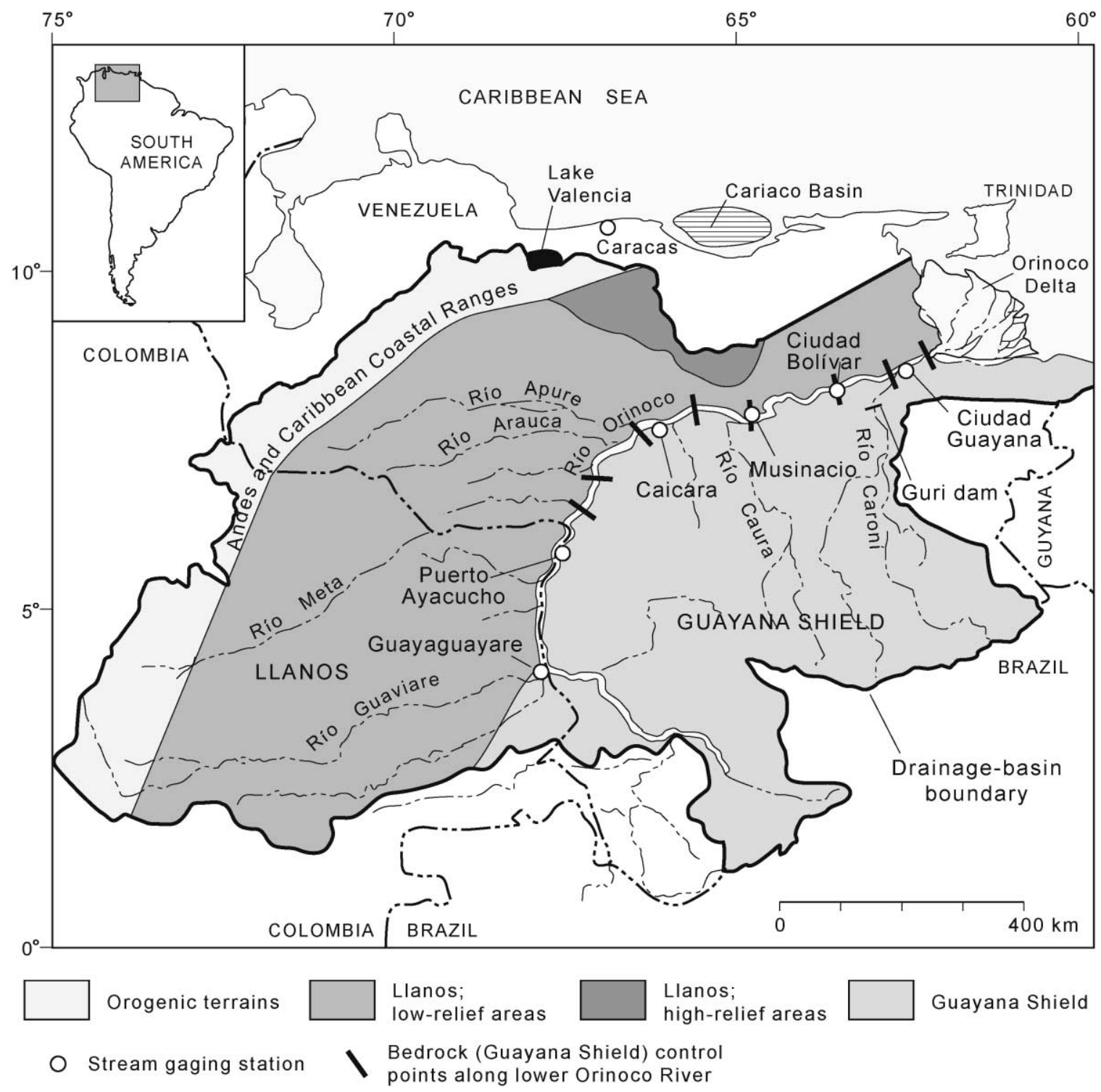

Fig. 3. Orinoco drainage basin showing principal tributaries, gauging sites, bedrock control points, and Guri Dam. Modified from Meade et al. (1983).

plains typify the Llanos. The sandy substrates of the Llanos are broadly inundated and extensively reworked by fluvial processes during the wet season, as recorded by the active, interconnected channel systems. Eolian reworking during the dry season significantly alters the drainage network, and thereby affects the discharge capacity of the Llanos drainage system (Johnsson et al., 1991).
Rainfall volumes within the Orinoco River basin and Delta typically range from 120 to $360 \mathrm{~mm}_{\text {year }}{ }^{-1}$ (Fig. 2c) and temperatures are uniform in the lowland regions, ranging from 25 to $28{ }^{\circ} \mathrm{C}$ throughout the year. The Intratropical Convergence Zone (ITCZ) controls the Orinoco basin climate. The ITCZ is the latitudinal belt along the equator where the easterly Trade Winds of both hemispheres converge and 
Table 1

Fundamental characteristics of the Amazon and Orinoco drainage basins, rivers, and deltas

\begin{tabular}{|c|c|c|}
\hline Characteristics & Orinoco & Amazon \\
\hline Drainage basin area $\left(10^{6} \mathrm{~km}^{2}\right)$ & $1.1^{(1)}$ & $5.9^{(2)}$ \\
\hline Main channel length (km) & about $770^{(3)}$ & $4000^{(4)}$ \\
\hline Main channel geomorphology & straight and anastomosing $^{(5)}$ & broadly meandering to anastomosing ${ }^{(4)}$ \\
\hline $\begin{array}{l}\text { River floodplain area, not } \\
\text { including delta }\left(\mathrm{km}^{2}\right)\end{array}$ & $77,000^{(3)}$ & $170,000^{(3)}$ \\
\hline $\begin{array}{l}\text { Valley length: fringing } \\
\text { floodplain area }\left(\mathrm{km}^{-1}\right)\end{array}$ & $9.3^{(3)}$ & $40^{(3)}$ \\
\hline $\begin{array}{l}\text { Floodplain lake coverage } \\
\text { (percent of total floodplain area) }\end{array}$ & $7^{(5)}$ & $11^{(5)}$ \\
\hline $\begin{array}{l}\text { Typical river channel width } \\
\text { and depth in lower reaches }(\mathrm{m})\end{array}$ & $2000,10-25^{(5)}$ & $5000,20-50^{(5)}$ \\
\hline $\begin{array}{l}\text { Annual water discharge } \\
\left(10^{12} \mathrm{~m}^{3} \text { year }^{-1}\right)\end{array}$ & $1.2^{(6)}$ & $6.3^{(6)}$ \\
\hline Time of peak water discharge & August-September ${ }^{(1)}$ (Fig. 4) & May-July ${ }^{(7)}$ \\
\hline $\begin{array}{l}\text { Mean annual variation in river } \\
\text { stage in lower reach }(\mathrm{m})\end{array}$ & $12^{(5)}$ (Fig. 4) & 10 \\
\hline $\begin{array}{l}\text { Ratio to peak to low } \\
\text { water discharge }\end{array}$ & $8: 1$ to $54: 1$, average of $26: 1^{(8)}$ & $2: 1$ to $3: 1^{(9)}$ \\
\hline $\begin{array}{l}\text { Drainage basin specific } \\
\text { discharge }\left(\mathrm{mm} \mathrm{year}^{-1}\right)\end{array}$ & $1300^{(5)}$ & $1200^{(5)}$ \\
\hline $\begin{array}{l}\text { Annual sediment discharge } \\
\left(10^{6} \text { metric tons year }^{-1}\right)\end{array}$ & $150^{(1)}$ & $1200^{(7)}$ \\
\hline Major sediment source & Andes (about 90\%) ${ }^{(1)}$ & Andes (about $90 \%)^{(7)}$ \\
\hline Time of peak sediment discharge & April-May, October-November ${ }^{(1)}$ (Fig. 4b) & February-April ${ }^{(7)}$ \\
\hline $\begin{array}{l}\text { Average dissolved solid concentration } \\
\text { in lower reaches of river }\left(\mathrm{mg} \mathrm{l}^{-1}\right)\end{array}$ & $125^{(5)}$ & $190^{(5)}$ \\
\hline $\begin{array}{l}\text { Dissolved load discharge } \\
\quad\left(10^{6} \text { metric tons year }^{-1}\right)\end{array}$ & $28.6^{(10)}$ & $290^{(11)}$ \\
\hline $\begin{array}{l}\text { Predominant grain size of sediment } \\
\text { delivered to delta }\end{array}$ & about $80 \%$ silt and clay $(<0.1 \mathrm{~mm})^{(8)}$ & $85 \%$ to $95 \%$ silt and clay ${ }^{(12)}$ \\
\hline Delta-plain area $\left(\mathrm{km}^{2}\right)$ & 22,000 & $25,000^{(3)}$ \\
\hline Tidal range at coast & to $2.6 \mathrm{~m}$ & to $6 \mathrm{~m}^{(13)}$ \\
\hline Wave energy & low & low to moderate ${ }^{(13)}$ \\
\hline Littoral current velocity $\left(\mathrm{cm} \mathrm{s}^{-1}\right)$ & $\begin{array}{l}25-75 \text { on Atlantic shelf, to } \\
100 \text { in Boca de Serpientes } \\
(14)\end{array}$ & commonly exceeding $50^{(13)}$ \\
\hline $\begin{array}{l}\text { Influence of major tropical } \\
\text { storms on coast }\end{array}$ & low & very low ${ }^{(13)}$ \\
\hline Thickness of Holocene delta (m) & to $>100^{(15)}$ & $30^{(16)}$ \\
\hline
\end{tabular}

Data sources: ${ }^{(1)}$ Meade et al. (1990). ${ }^{(2)}$ Coleman (1981). ${ }^{(3)}$ Hamilton and Lewis (1990). ${ }^{(4)}$ Dunne et al. (1998). ${ }^{(5)}$ Lewis et al. (1995). ${ }^{(6)}$ Meade (1996). ${ }^{(7)}$ Meade et al. (1985). ${ }^{(8)}$ Nordin et al. (1994). ${ }^{(9)}$ Kineke and Sternberg (1995). ${ }^{(10)}$ Ramirez et al. $(1992) .{ }^{(11)}$ Stallard (1985). ${ }^{(12)}$ Kuehl et al. (1986). ${ }^{(13)}$ Nittrouer et al. (1986b). ${ }^{(14)}$ Van Andel (1967). ${ }^{(15)}$ Geohidra Consultores (1997b). ${ }^{(16)}$ Sommerfield et al. (1995).

produce warm, humid, unstable air masses that generate large volumes of rainfall. The ITCZ seasonally migrates across about $15^{\circ}$ latitude. Because the Orinoco basin lies along the northern boundary of this migration belt, marked wet (June through November) and dry (December through April) seasons characterize the region.

The marked differences between wet and dry season rainfall volumes induce large fluctuations in
Orinoco discharge (Fig. 4a). Mean monthly discharge for the period 1970 to 1981 varied between 1330 and $81,100 \mathrm{~m}^{3} \mathrm{~s}^{-1}$. The ratio of maximum to minimum monthly discharge recorded for each year ranged from $8: 1$ to $54: 1$, with an average of $26: 1$ (Nordin et al., 1994). The ratio between low and high annual discharge for the Orinoco River is one of the largest among major world rivers. Seasonal stage fluctuations are typically $12 \mathrm{~m}$ in the lower river (Fig. 4). 

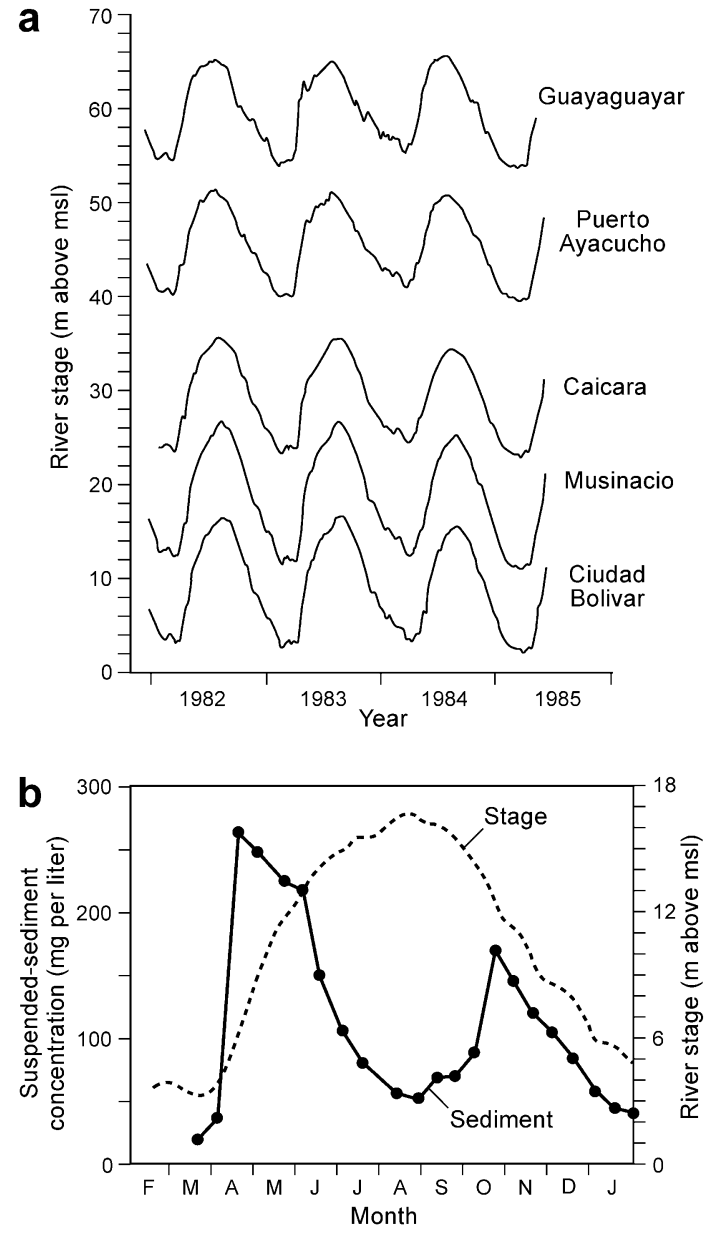

Fig. 4. Hydrology of the Orinoco River. (a) Stage at several stations along the Orinoco River. See Fig. 3 for locations of gauging sites. Modified from Pérez-Hernández and López (1998). (b) Monthly sediment and water discharge in the lower Orinoco River (Ciudad Bolivar). Modified from Meade et al. (1990).

Unlike the unimodal water discharge oscillations, sediment discharge in the lower Orinoco River is bimodal (Fig. 4b), with a maximum during rising flood discharge (April-May), a minimum during peak water discharge (August-September), and a secondary maximum during the recession of flood discharge (October-November). As the annual flood discharge initiates, the sparsely vegetated sediment deposited during the late flood stage of the previous year, together with the large volumes of sediment redistributed by winds during the dry season, are easily entrained (Nordin and Pérez-Hernández, 1989;
Carbón and Schubert, 1994). As the river approaches peak stage, water levels in the main channel exceed those of the tributaries draining the low-gradient Llanos, causing tributary flood water to pond at the intersections, which promotes temporary deposition of sediment loads. As the flood stage in the Orinoco channel recedes, a portion of the sediment deposited at the intersections of the main tributaries is remobilized, causing a late flood-period peak in sediment discharge (Meade et al., 1990) (Fig. 4b).

During the dry season, $30 \%$ to $40 \%$ of the river channel bottom may be exposed, and the system largely converts to an eolian regime. Prevailing winds from the northeast transport river sediment upriver, which partially disrupts the active channel system and makes sediment available for entrainment downstream during the early phases of the following flood period (Nordin and Pérez-Hernández, 1989; Carbón and Schubert, 1994).

Major Orinoco tributaries include the Guaviare, Meta, Apure, Caura, and Caroní (Fig. 3). The Guaviare River drains part of the Colombian Andes and contributes about $18 \%$ of water (Fig. 5a) and about $20 \%$ of Orinoco sediment discharge (Fig. $5 \mathrm{~b}$ ) to the Orinoco River. The Meta River drains another segment of the Colombian Andes and contributes about $10 \%$ of water and about $50 \%$ of Orinoco sediment discharge. The Apure River drains most of the eastern slope of the high Andes of Venezuela and contributes about $5 \%$ of water and about $20 \%$ of Orinoco sediment discharge. The Caura and Caroní drain the Guayana Shield and contribute about $20 \%$ of water but less than $5 \%$ of sediment discharge to the Orinoco River (Meade et al., 1990). In essence, the left-bank tributaries are muddy water streams, draining the Andes and Coastal Ranges, and the right-bank tributaries are black water or clear water streams draining the Guayana Shield. Overall, the Orinoco River waters contain relatively low concentrations of sediment; the river has the third largest water but only the eleventh largest sediment discharge in the world (Milliman and Meade, 1983). Even though the leftbank tributaries are relatively muddy, they cross the broad Llanos foreland basin where much of the Andean-derived sediment is deposited and retained. Orinoco River dissolved solid concentrations are also relatively low (Table 1), because the deeply weathered soils of the Guayana Shield and the mature sediments 


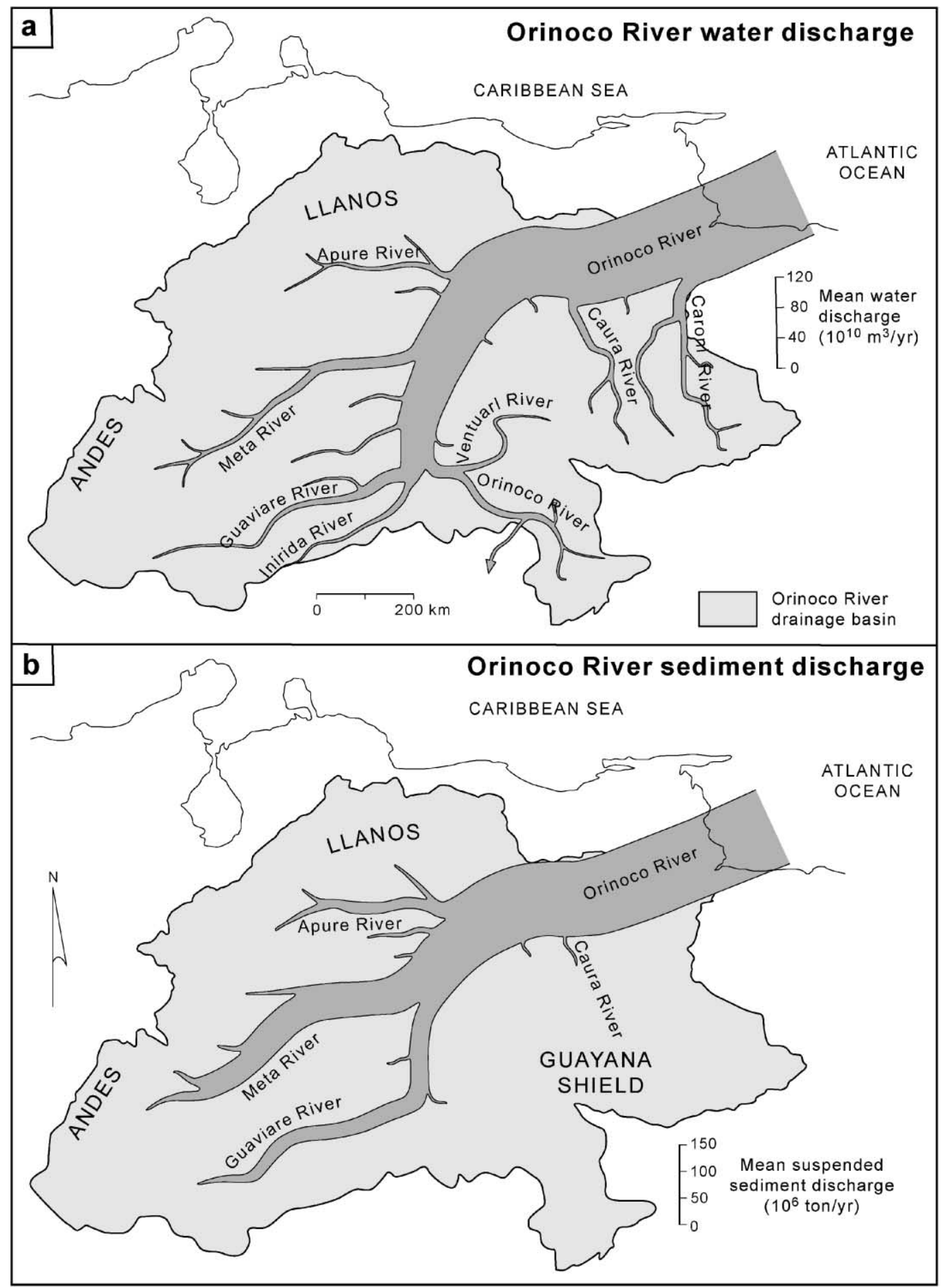

Fig. 5. Water and sediment discharge of major Orinoco River tributaries. Modified from Meade et al. (1990). 
of the Llanos regions produce little dissolved material (Stallard, 1985; Stallard et al., 1991).

Regional tilting to the south-southeast induced by uplift of the Andes and northern Coastal ranges, and lateral expansion of the Llanos foreland basin sediments maintain the course of the Orinoco at or very near the boundary between the bedrock of the Guayana Shield and the foreland basin clastic wedge (Fig. 3). As a result, the asymmetric alluvial valley of the lower Orinoco River is generally confined between igneous and metamorphic outcrops of the Guayana Shield along the right bank and erosional scarps of the Pleistocene Mesa Formation along the left bank (Stallard, 1987). At a number of locations along the lower river, the floodplain and channel cross rock outcrops of the Guayana Shield. These bedrock control points stabilize channel position and form substantial but navigable rapids. There are eight major control points along the lower Orinoco River (Fig. 3), which subdivide the channel and floodplain into nine distinct hydrogeomorphic and ecologic zones (Hamilton and Lewis, 1990). These bedrock control points also influence floodplain development by limiting lateral channel migration and modifying peak discharge by constricting overbank flow.

The Orinoco River floodplain can be subdivided into fringing floodplain and internal deltas (Hamilton and Lewis, 1990). Fringing floodplains border and are generally parallel to the river channel; they develop by lateral migration and avulsion of the river channel and by vertical accretion during seasonal floods. Fringing floodplains of the Orinoco main channel cover about $7000 \mathrm{~km}^{2}$ and extend from the Meta River to the delta apex. Upstream from the Meta River, the Orinoco floodplain is much less extensive (Hamilton and Lewis, 1990).

Internal deltas, which are areas of significantly broadened flood plain, are related to bedrock constrictions in the river valley that are located just downstream of intersections of major tributaries. During the wet season, these bedrock constrictions cause Orinoco stages to exceed those of the Llanos tributaries, which in turn cause water and sediment to pool at the intersections and form extensive left-bank floodplains at the mouths of these tributaries. Welcomme (1979) determined that the Orinoco internal delta floodplains encompass about $70,000 \mathrm{~km}^{2}$, principally at the intersections of the Apure and Arauca, and the Orinoco River (Fig. 3). Meade et al. (1983) estimated that as much as half of the sediment discharged by the Meta River during flood stage is temporarily deposited in the internal deltas. The bimodal peak in sediment discharge to the delta (Fig. 4b) is caused largely by transport of sediment during the ascending flood discharge, temporary storage of sediment in the internal deltas during peak flood discharge, and remobilization of these stored sediments during receding discharge.

The Orinoco River has a relatively low floodplain area per unit channel length of $9.3 \mathrm{~km}^{2} \mathrm{~km}^{-1}$ (as compared to about $40 \mathrm{~km}^{2} \mathrm{~km}^{-1}$ for the Amazon River). The relatively narrow floodplain results from (1) active encroachment of the left-bank (north) valley wall onto the floodplain as the Llanos foreland basin clastic wedge expands onto the Guayana Shield, and (2) inhibition of floodplain expansion by lateral channel migration by bedrock control points (Hamilton and Lewis, 1990; Meade, 1994). The low floodplain area per unit channel length promotes large differences between wet and dry season river stages (Fig. 4a).

\section{Amazon river and delta}

The Amazon River maintains the world's largest fresh water discharge and one of the three largest sediment discharges (Table 1). The drainage basin encompasses about $5.9 \times 10^{6} \mathrm{~km}^{2}$, and in many respects is similar to the Orinoco drainage basin. In both drainage basins, the Andes comprises the western margin and supplies about $90 \%$ of the river sediment (Fig. 2a,b). In both drainage basins, large portions are underlain by deeply weathered, moderate- to low-relief shield, and other portions are underlain by low-relief foreland basin sediments. In both drainage basins, the climate is largely tropical, large portions are covered with tropical rainforest with lesser but significant tropical savannas (Fig. 2d), and the main river channel is low gradient (Fig. 2b). There are, however, marked differences between Amazon and Orinoco water and sediment discharges, which largely reflect differences in rainfall volumes and distribution, and drainage basin sizes (Figs. 2c and 6).

The temporal distribution of wet and dry seasons in the Amazon basin is more complex than in the Orinoco basin (Meade et al., 1991). The Amazon 

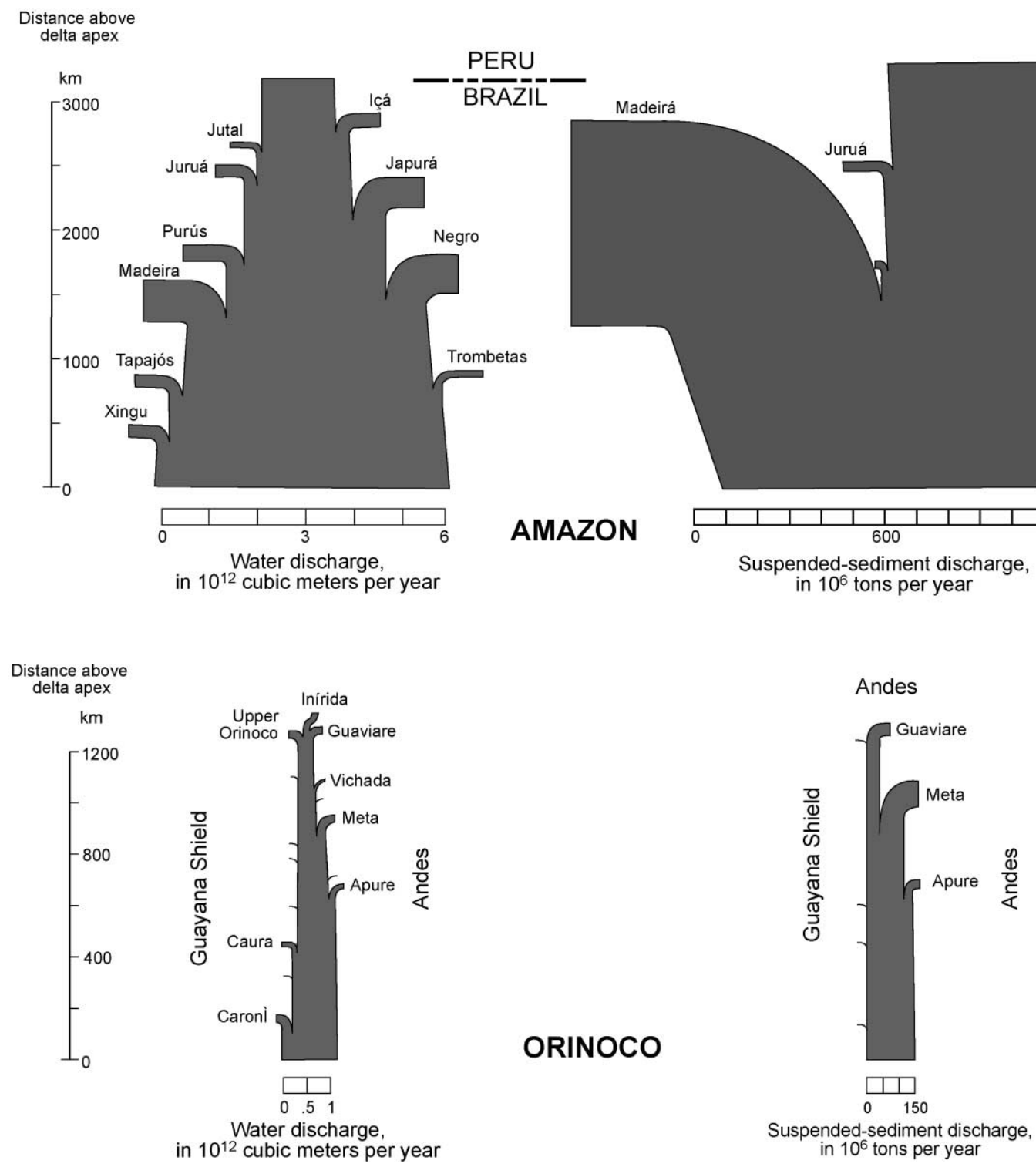

Fig. 6. Water and sediment discharges from the Amazon and Orinoco River systems. Modified from Meade (1996) by inclusion of newer Amazon water-discharge data from Carvalho and da Cunha (1998; Table 1) and newer Amazon sediment discharge data from Dunne et al. (1998; table 2).

River mainstem flows near the equator, receiving fresh water input from both northern and southern (hemisphere) tributaries. Because the ITCZ shifts seasonally from southern latitudes to northern latitudes and back again, the wet season in the southern tributaries is nearly 6 months out of phase with wetseason discharge from the northern tributaries. Where- as water discharges in some tributaries vary seasonally by factors of 10 or more, those in the Amazon mainstem typically vary by only 2 or 3 .

River-borne sediments typically consist of $85 \%$ to $95 \%$ suspended silt and clay. Sediment discharge in the Amazon mainstem usually reaches its maximum in March to April, preceding the peak water discharge 
by 1 to 2 months. Minimum sediment discharge occurs in October and November (Kineke and Sternberg, 1995). Meade et al. (1985) demonstrated that suspended sediment is stored in the lower Amazon during rising stages of the river and is resuspended during falling river stages as river gradients increase. This pattern of storage and resuspension damps extreme values of high and low sediment discharge and tends to keep sediment discharge at the downstream gauging station at Obidos between $3.0 \times 10^{6}$ and $3.5 \times 10^{6}$ metric tons day ${ }^{-1}$ for a large portion of the year.

Of the about $1.2 \times 10^{9}$ tons of sediment that pass the last downstream gauging station at Obidos each year, about $1.0 \times 10^{9}$ tons (perhaps even less) are delivered to the Amazon continental shelf. The Amazon has a relatively small delta plain, which is mostly composed of estuarine islands (Franzinelli, 1992). A large sedimentary prism (with topset, foreset, and bottomset beds), however, is developing on the shelf

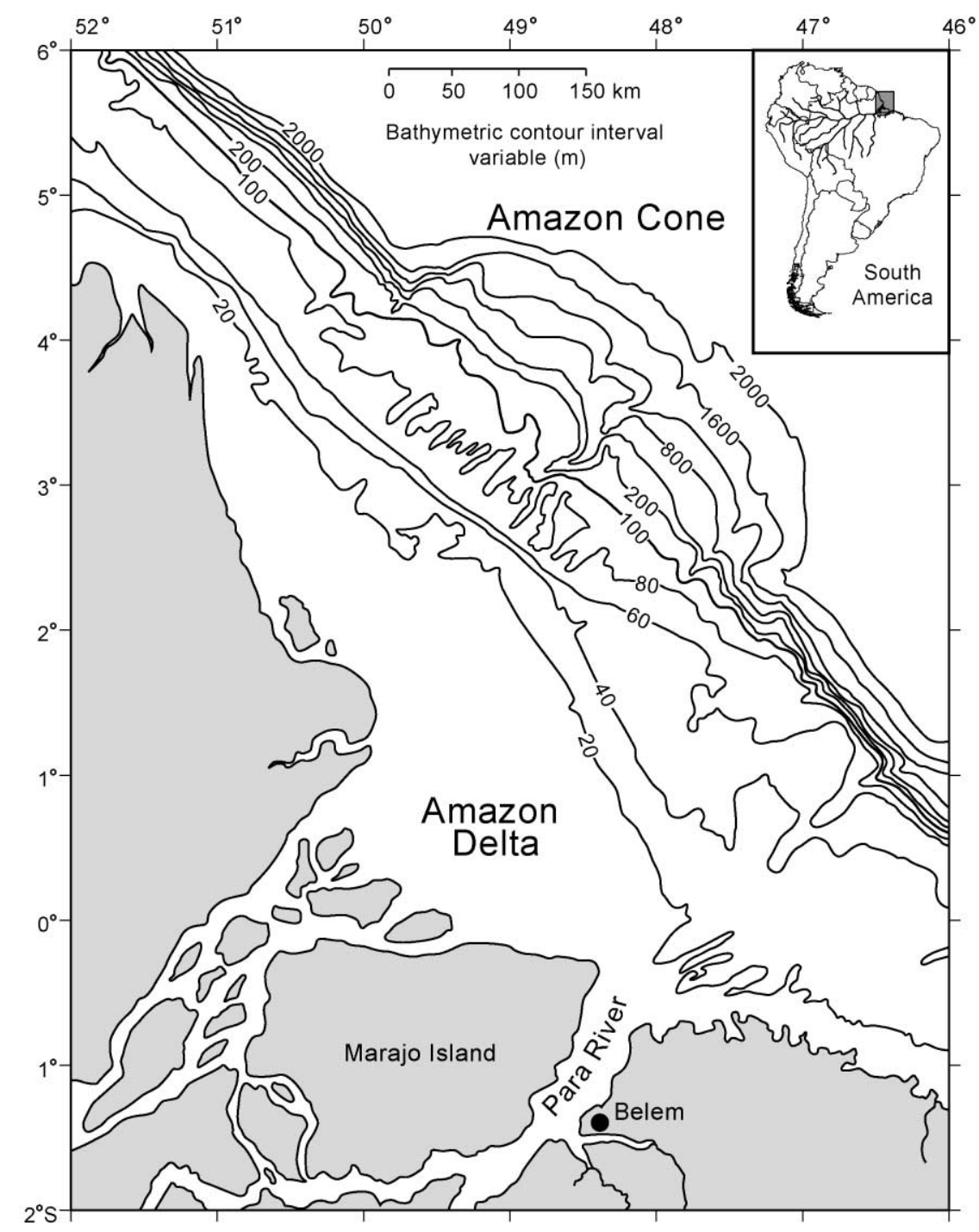

Fig. 7. Bathymetric map of the continental shelf adjacent to the Amazon River mouth, showing the subaqueous Amazon Delta. Modified from Nittrouer et al. (1986b). 
seaward of the river mouth. The subaqueous Amazon Delta extends northward for several hundred kilometers (Fig. 7) and the Holocene section has a maximum thickness of about $30 \mathrm{~m}$ (Nittrouer et al., 1995).

Amazon water discharge is so consistently large that seawater never enters the river mouth and many characteristic estuarine processes, including circulation and sediment transport, occur on the Amazon shelf (Kineke and Sternberg, 1995). At the river mouth the tides may exceed $6 \mathrm{~m}$, and tidal currents of $100 \mathrm{~cm} \mathrm{~s}^{-1}$ have been measured on the shelf (Nittrouer et al., 1986a,b). The North Equatorial littoral current flows northwestward at speeds generally exceeding $50 \mathrm{~cm} \mathrm{~s}^{-1}$ (Nittrouer et al., 1986a). Surface waves are primarily generated by prevailing Trade Winds, but inner shelf fluid muds dissipate most wave energy as they approach the coast (Nittrouer et al., 1986b). Major storms do not affect this tropical coastal region.

Like many deltas along high-energy coastal regimes, the majority of topset beds of the Amazon are subaqueous and topset surfaces do not develop at depths less than $15 \mathrm{~m}$ (Kuehl et al., 1986, 1997). At shallower depths, intense and persistent wave and tidal activity precludes sediment deposition. Suspended sediment transport and distribution on the submerged Amazon Delta is dominated by sediment-rich bottom suspensions (including fluid muds). This mud and water mix is in concentrations between 10 and $400 \mathrm{~g}$ $1^{-1}$, as much as $7-m$ thick on the inner and middle shelf, and covers between 5700 and $10,000 \mathrm{~km}^{2}$ (Kineke and Sternberg, 1995). Approximately 90\% of the Amazon suspended sediment in the Amazon Delta is in the form of these fluid muds.

Development and distribution of fluid muds on the Amazon and Guiana shelves have been linked to tideand wave-induced resuspension and concentration associated with a bottom salinity front (Allison et al., 2000). As Amazon River water is discharged onto the marine shelf, density differences between the fresh and marine water induce formation of a fresh water plume that is advected northwestward by the North Equatorial littoral current (southern equivalent of the Guayana Current). A bottom salinity front develops along the seaward boundary of this sediment rich, fresh water plume. This front migrates across the shelf with the tides and is located 50 to $100 \mathrm{~km}$ offshore at about 10- to 20-m water depth (Allison et al., 2000).

Kuehl et al. (1986) estimated that about $6 \times 10^{8}$ tons of sediment are deposited on the shelf annually as foreset and bottomset beds, causing progradation of the subaqueous delta towards the shelf break. The remainder of the sediment (about $2 \times 10^{8}$ to $3 \times 10^{8}$ tons year ${ }^{-1}$ ) is transported northwestward along the shelf toward the Guiana and Orinoco coast (Nittrouer et al., 1995; Kuehl et al., 1986). Approximately half the sediment transported northwest of the Amazon Delta to the Guiana coast is in the form of turbid suspensions (100 to $1000 \mathrm{mg}^{-1}$ ), whereas the other half is in a less concentrated form along the middle shelf and is advected northwestward by the North Equatorial Current (Eisma et al., 1991; Colin and Bourles, 1992).

\section{Guiana coast}

\subsection{General characteristics}

The Holocene coastal plain along the Guiana coast (Fig. 2a) comprises the longest actively accreting muddy coast in the world. The Guiana coastal plain spans $1600 \mathrm{~km}$ from the Amazon to Orinoco Rivers, extends about $30 \mathrm{~km}$ inland and $30 \mathrm{~km}$ seaward onto the shelf, and the Holocene section has a maximum recorded thickness of about $25 \mathrm{~m}$ (Allison and Nittrouer, 1998). The Holocene portion of the Guiana coastal plain is composed largely of Amazon River

Fig. 8. (a) Major physiographic features of the French Guiana, Suriname, and Guyana coast. (b) Model of mudcape development. Mudcapes primarily develop by alongshore (downdrift) accretion of a succession of subtidal clinoform mud and silt, mangrove muds, and supratidal mud and silt. Offshore, seaward mudflat accretion takes place along the outer flank of the mudcape after passage of the rapidly accreting mudcape point. The mudcape and new mudflat are deposited above old tidal flat deposits that accumulated along the flank of a previous generation of mudcapes, and are incised by the local river mouth. Shoreface muds are offlapping relict inner-shelf muds. Modified from Allison et al. (1995). (c) Oblique aerial photograph of a small mudcape along the larger Caño Mariusa mudcape (central Orinoco Delta coast), demonstrating that mudcapes develop at a variety of scales. Note extensive mangrove forest, which is common along the Orinoco coast. 
a

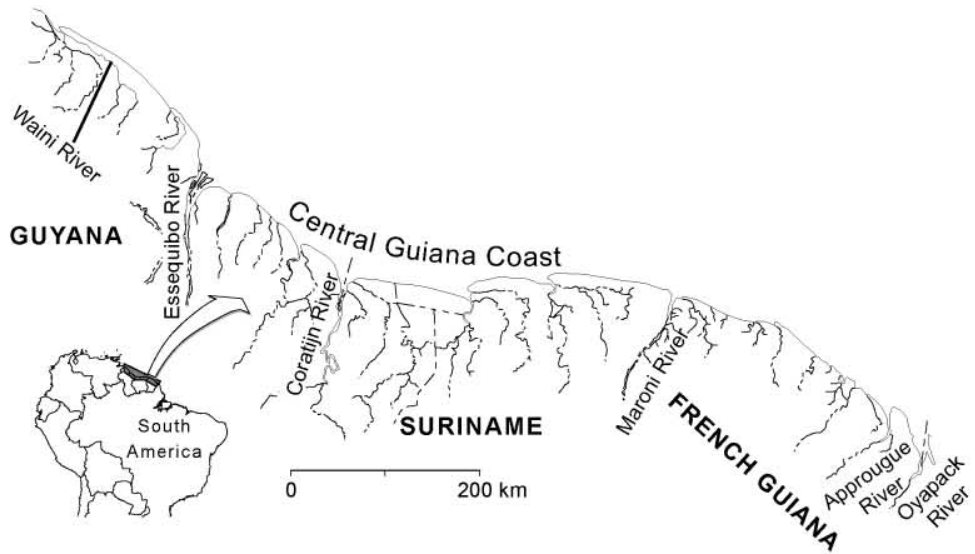

b

Direction of view of aerial photograph in (c)

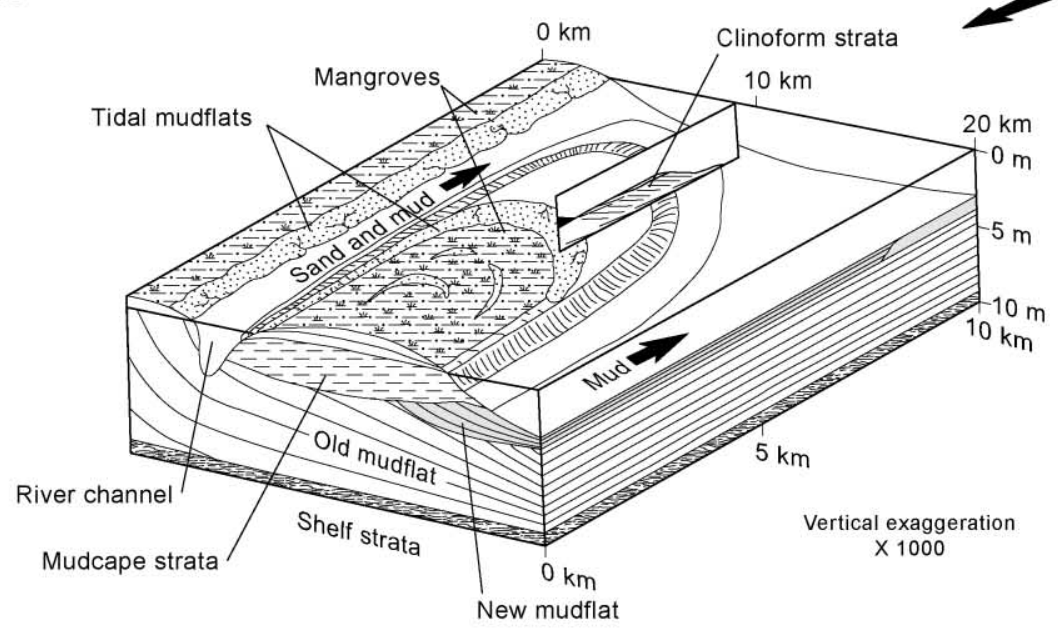

C

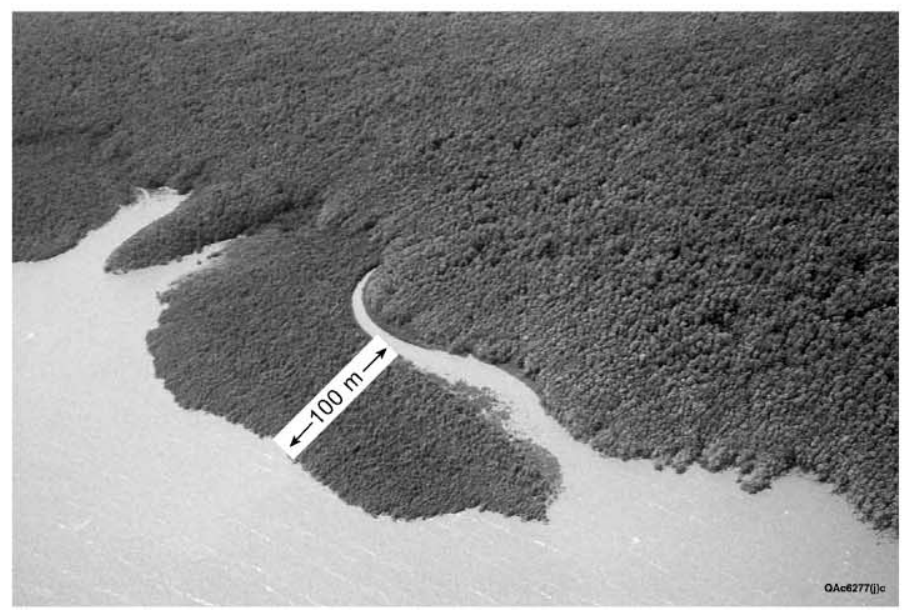


sediments with only a very small portion derived from coastal plain rivers. Like the Orinoco, the general morphology of the Guiana coastal zone consists of alternating mudcapes and estuaries (Figs. 1 and 8a). Unlike the relatively unpopulated Orinoco coast, much of the Guiana coast is populated: coastal lowlands have been drained and modified for agriculture and habitation, and coastal structures have been constructed in attempts to halt shoreline erosion and stabilize positions of river mouths (Daniel, 1988; Wong et al., 1998).

The Holocene coastal plain, which is in effect an extension of the Amazon Delta, has a chenier-plain morphology of coast-parallel sandy ridges that extend 2 to $4 \mathrm{~m}$ above mean sea level ( $\mathrm{msl}$ ), and are separated by muddy mangrove swamps and minor marsh (Brinkman and Pons, 1968; Vann, 1969; Rine and Ginsburg, 1985; Prost, 1992). Cheniers commonly occur in bundles adjacent to river mouths. On the landward side of the chenier plains, broad areas of ombrogenous peats cover large tracts of earlier Holocene-age deposits, are up to 4-m thick, and locally form broad mounds with radial drainage patterns (Brinkman and Pons, 1968; Wong et al., 1998). Although the Guiana coastal plain rivers contribute relatively little sediment volume to the muddy coast (Brinkman and Pons, 1968; Allison et al., 2000), they are the primary source of chenier-ridge sand (Vann, 1969; Djuwansah et al., 1992).

Tidal mud flats, typically 2 - to 5 -km wide at low tide, characterize large segments of the coastline; along their landward side, mangroves encroach onto the mud flats (Wells and Coleman, 1981b; Allison et al., 1995). Portions of the coastline are erosional and are typified by modest beach development and mangroves collapsing into the surf.

Tidal range along the Guiana coast is about 1 to 2.5 m. Waves on the shelf are typically 1- to 3-m high and exceed $4 \mathrm{~m}$ less than $1 \%$ of the time. Waves typically approach the coast $3^{\circ}$ to $8^{\circ}$ east of north. On the inner continental shelf, waves are typically 0.5 to $1 \mathrm{~m}$ with a period of $8 \mathrm{~s}$ (Wells and Coleman, 1981a).

The Guayana littoral current is a major process in transporting Amazon River sediments northwestward along the coast. The highest velocities and greatest transport potential of the Guayana Current are 100 to $200 \mathrm{~km}$ offshore, but sediment concentrations there are $<10 \mathrm{mg}^{-1}$. Closer to shore (20 to $40 \mathrm{~km}$ from coast), residual currents are 10 to $20 \mathrm{~cm} \mathrm{~s}^{-1}$, but suspended sediment concentrations (fluid muds) commonly exceed $1000 \mathrm{mg} \mathrm{l}^{-1}$ (Wells and Coleman, 1981a). In the nearshore zone, waves and tides induce littoral currents that perform the majority of geomorphic work along the coast. Tropical storms are not a major factor in the region, but heavy rainfall associated with southward movement of the ITCZ each year causes flooding in lowland areas of the coastal plain. The strong easterly winds that prevail during this period generate waves up to $4 \mathrm{~m}$ in height, which causes widespread erosion and sediment transport along the coast (Daniel, 1988).

The high sediment concentrations along the shallow shelf and coast profoundly affect (damp) the hydrodynamic regime, especially the rate of wave attenuation. Two major processes for transport and deposition of Amazon River sediment along the Guiana coast have been identified: mudbank migration and mudcape accretion (Allison et al., 2000). Both mudbank and mudcape sedimentation produce large prisms of mud in the intertidal zone that are rapidly colonized by mangroves.

\subsection{Mudbanks}

Mudbanks are nearshore/shallow shelf features composed primarily of silty clay that has the consistency of fluid mud. Mudbanks typically contain $10^{9}$ $\mathrm{m}^{3}$ of mud and extend obliquely offshore to about the 20-m isobath (Rine and Ginsburg, 1985). Mudbanks have as much as 5-m relief, thin both seaward and landward, and may or may not be attached to the coast. Mudbanks and intervening interbank zones migrate northwestward along the coast at an average velocity of $1.1 \mathrm{~km}$ year ${ }^{-1}$ off Guyana, $1.5 \mathrm{~km} \mathrm{year}^{-1}$ off Suriname, and $0.9 \mathrm{~km} \mathrm{year}^{-1}$ off French Guiana (Eisma et al., 1991). The alongshore recurrence of these mudbanks is such that they can be thought of as mud waves with a wavelength of $45 \mathrm{~km}$ and a periodicity of 30 years (Eisma et al., 1991). Mudbanks migrate by the combination of the Guayana Current coming from the east and the waves that are generated by the Trade Winds coming from the northeast. As the waves pass over the mudbanks, they are transformed into solitary waves that agitate, suspend, and transport the mud to the west-northwest (Wells and Coleman, 1981a). 
In the 10 - to $60-\mathrm{km}$ section of coastline enveloped by a bank, wave damping over the mudbank surface promotes vertical accretion in the nearshore and lateral accretion (to $200 \mathrm{~m} \mathrm{year}^{-1}$ ) along the shoreline (Wells and Coleman, 1981a). Progradation of mangroves over the mudflats enhances vertical accretion along the coast. The areas between mudbanks are subject to higher wave energy that scours mudflat deposits, and may erode a substantial portion of the mangrove fringe.

Colin and Bourles (1992) inferred that the intensity and direction of the Guayana Current, which is primarily controlled by the Trade Winds, is seasonal. They inferred that seasonal cycles in Trade Wind and Guayana Current intensity and direction are related to migration of the ITCZ. Colin and Bourles (1992) also inferred that changes in Guayana Current intensity significantly influence mudbank dynamics. Wells and Coleman (1981b) proposed that periods of enhanced mud accumulation and shoreline progradation are associated with semiannual and 18.6-year tidal cycles, which expose broad areas of mudflats and provide opportunities for colonization by mangroves. A 30year coastal erosion-sedimentation cycle associated with mudbank migration has been identified in numerous investigations of the region (e.g., Wells and Coleman, 1981b; Eisma et al., 1991). Daniel (1988) suggested that this erosion-sedimentation cycle actually varies between 17 and 36 years.

\subsection{Mudcapes}

Mudcapes are rounded, elongate promontories that characterize the Guiana (and Orinoco) coast (Allison et al., 1995). Mudcapes have a similar morphology to sand spits, although their origins are distinct (Fig. 8b). Allison et al. (1995) identified 16 major mudcapes along the Guiana coast, and many smaller mudcapes occur as well (Fig. 8c). The major mudcapes are typically 5 - to $10-\mathrm{km}$ wide (perpendicular to the coast) and as much as $100-\mathrm{km}$ long (parallel to the coast), and most commonly occur on the updrift bank of coastal plain river mouths. Allison et al. (1995) documented that mudcapes of northern Brazil are accreting downdrift at a rate of 57 to $114 \mathrm{~m} \mathrm{year}^{-1}$. Accretion is primarily maintained by sediment flux along shore rather than from the river that the mudcape is diverting. Alongshore, accretion of mudcapes diverts these rivers north and northwestward, resulting in a systematic reorientation of river courses to the north and northwest as Guiana coastal plain rivers approach the coast (Fig. 8c).

Allison et al. (2000) proposed that mudbanks form from concentrations of Amazon River suspended material that are supplied from the middle shelf and temporarily accumulates in the subtidal/intertidal area of mudcapes. A bottom salinity front occurs along the coast of northern Brazil and is located within $20 \mathrm{~km}$ of the coast in 5 to $15 \mathrm{~m}$ of water depth. This density interface apparently provides a pathway for dense bottom suspensions to reach the mud flats through tidal excursion and solitary wave shoaling (Allison et al., 2000). Seasonal and decadal trade wind cycles vary the access of fluid muds to the nearshore zone, resulting in alternating periods of mudbank development and sediment reworking along the coast (Allison et al., 2000).

\section{Orinoco Delta}

The Orinoco Delta plain is a mosaic of interdistributary swamps and marshes distributed among an extensive network of distributary and tidal channels. Cursory inspection of a map or satellite mosaic of the delta reveals two distinct, roughly fan-shaped delta sectors: the south/southeastern sector, which comprises a complex of anastomosing channels and islands, and a central /northwest sector, which contains more widely spaced, relatively straight channels that subdivide broad interdistributary basins (Fig. 9a). The marked differences in geomorphic form and process as well as ecosystem structure and composition between the northwestern and southeastern delta reflect major differences in water and sediment regimes (Fig. 10). The southeastern (Río Grande) sector is fundamentally controlled by river and tidal processes and can be characterized as a river near the delta apex and an estuary near the coast, whereas the central/northwest sector is fundamentally controlled by tides and rainfall and to a lesser extent by river processes, and can be characterized as a coastal plain tidal swamp and marsh system.

The delta plain can also be subdivided into three coast-parallel sectors: (upper) river, (middle) river and tide, and (lower) tidal (Fig. 9b). The geomorphic, 

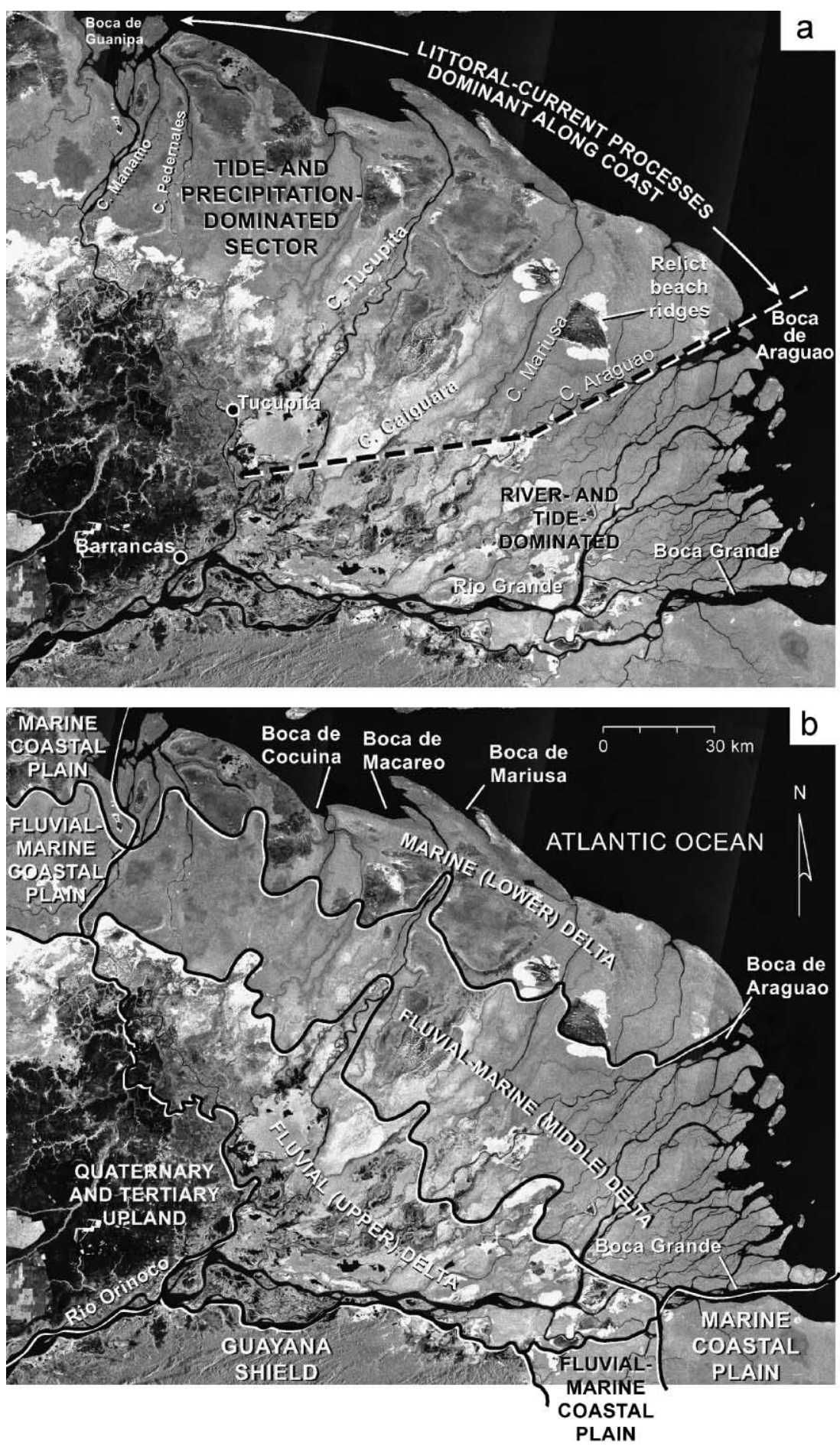

Fig. 9. Orinoco Delta hydrology and geomorphology. (a) River- and tide-dominated southeast versus tide- and precipitation-dominated central and northwestern sector. These regimes are largely determined by differential subsidence in the southeastern sector. (b) Upper (fluvial), middle (fluvio-marine), and lower (marine) delta. This tripartite, generally coast-parallel hydrologic regime is characteristic of tide-influenced deltas. 

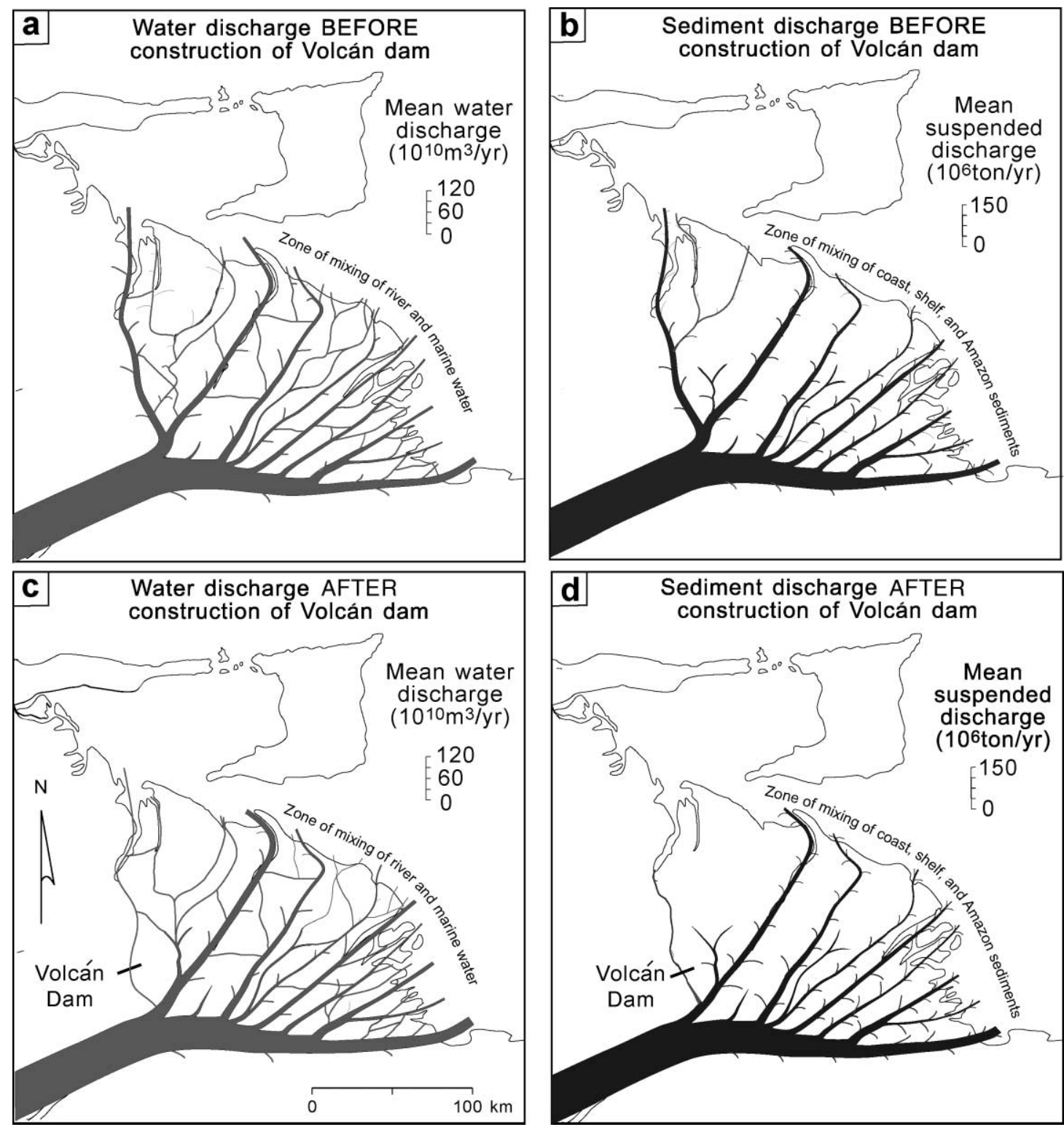

Fig. 10. Schematic diagram showing general distribution of water and sediment discharge in the Orinoco Delta before and after construction of Volcán Dam. The diagrams are not rigorously constructed (cf. Meade, 1994), but generally reflect the present and historical distribution of water and sediment discharge in the delta.

hydrologic, and ecologic structure and dynamics of the upper delta plain are controlled largely by river discharge and, to a lesser degree, by local rainfall. This portion of the delta plain is generally between 7 and $2.5 \mathrm{~m}$ in elevation, seasonally inundated, and naturally covered with deciduous forests (although a large portion has been cleared by humans). The substrate is a complex mixture of clay, silt, and sand with minor peat. The geomorphic, hydrologic, and ecologic structure and dynamics of the middle (fluviomarine) delta plain reflect the complex interaction among river discharge, tides, and local rainfall. This 
portion of the delta plain is generally between 2.5 and $<1 \mathrm{~m}$ in elevation, flooded for the majority of the year, and covered by evergreen and palm forest and herbaceous wetlands. The substrate is largely mud and/or peat (Fig. 11). The geomorphology, hydrology, and ecology of the lower delta plain are controlled primarily by tides but are also substantially influenced by the river and local rainfall. This portion of the delta generally ranges in elevation from $1 \mathrm{~m}$ above to $1 \mathrm{~m}$ below mean sea level, is perennially flooded, and sustains evergreen broadleaf forests, herbaceous marsh, and mangrove along the coast. The substrate is mostly peat and/or mud, but silt and sand (cheniers) are significant in some areas (Fig. 11).

The Orinoco, like many modern deltas, is but the latest in a series of a stacked delta sequence that began to develop in the Tertiary Period (Coleman, 1981; Stanley and Warne, 1994; Di Croce et al., 1999; Warne et al., 1999). The Orinoco is located within the Eastern Venezuelan Basin (EVB), which is a foredeep

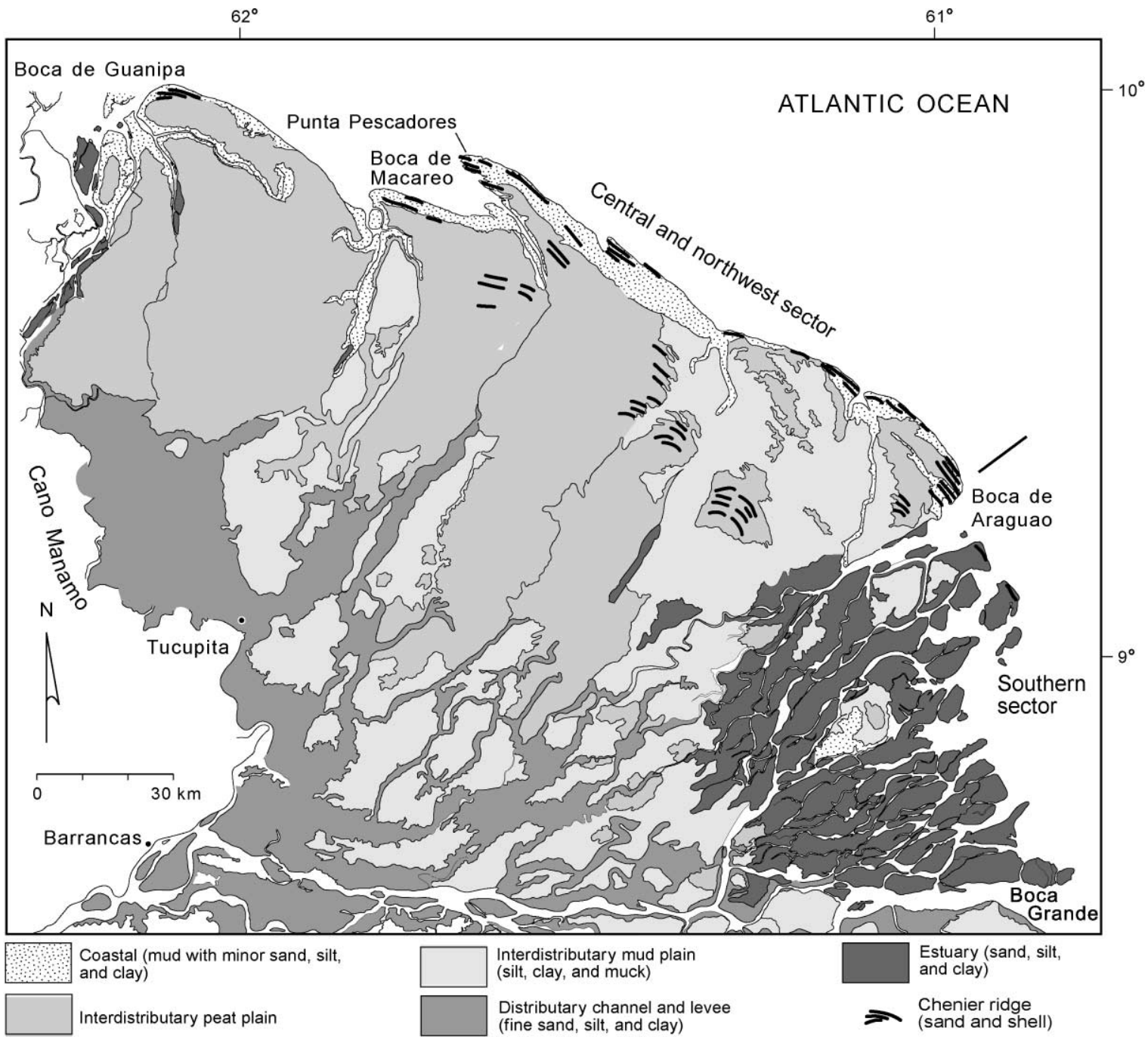

Fig. 11. General distribution of environments of deposition in the Orinoco delta plain. These subdivisions were derived from a geomorphic map of the delta plain (Warne et al., 1999, fig. 31). The majority of terrigenous substrates occur south and southwest, reflecting the influence of Río Grande, and formerly Caño Manamo, in the transport and distribution of terrigenous sediment. The peat plains of the central and northwestern delta currently receive little or no terrigenous sediment and maintain high water levels. 
trough associated with the South Caribbean Plate Boundary Zone (SCPBZ) (Fig. 12). Although no significant seismic activity has been reported in the Orinoco Delta, neotectonic features such as mud volcanoes and synclines and anticlines provide evidence that tectonic activity along the SCPBZ has been a major factor in the development of the Orinoco Delta.

The Orinoco, like many major deltas, is located within a portion of the coastal plain that is subsiding more rapidly than adjacent sectors (Nota, 1958; Brinkman and Pons, 1968). Subsidence associated with the

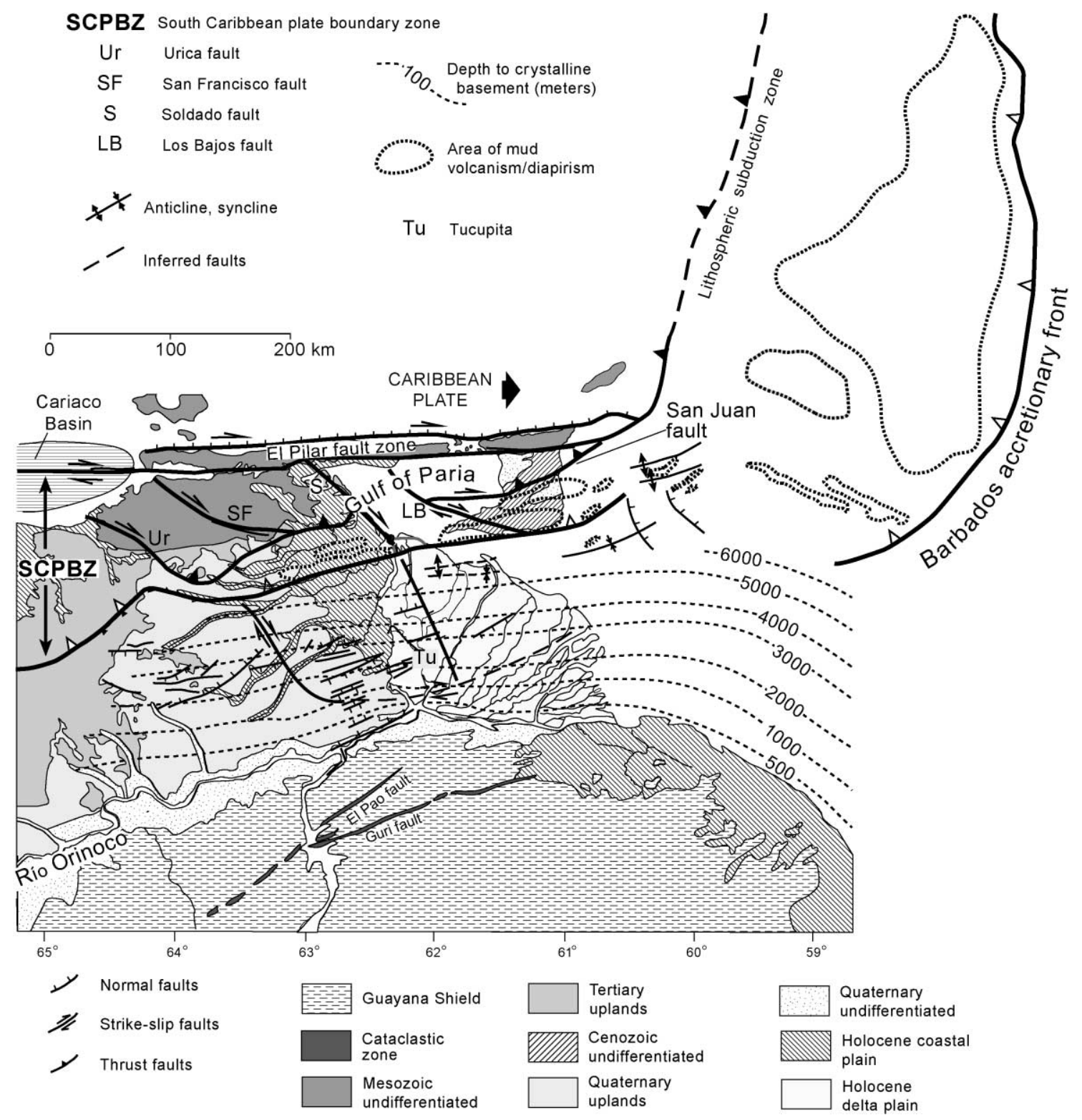

Fig. 12. Principal structural features and general geology of the Orinoco Delta region. Information derived from Pees et al. (1968), Case and Holcombe (1980), Leonard (1983), Pimentel-de-Bellizzia (1984), Robertson and Burke (1989), CVG (1991a-f), Beltrán (1993), Di Croce et al. (1999). 
ongoing development of the EVB has generated accommodation space for more than $30 \mathrm{~m}$ of Holocene deltaic sediment in the middle and $70 \mathrm{~m}$ in the lower delta plain (Geohidra Consultores, 1997b;
FUNINDES USB, 1998; Warne et al., 1999, in press). Preliminary estimates of Holocene subsidence rates, using radiocarbon-dated cores, range from 0.8 to 1.0 mm year ${ }^{-1}$ for the upper, 0.8 to $2.0 \mathrm{~mm}$ year $^{-1}$ for the
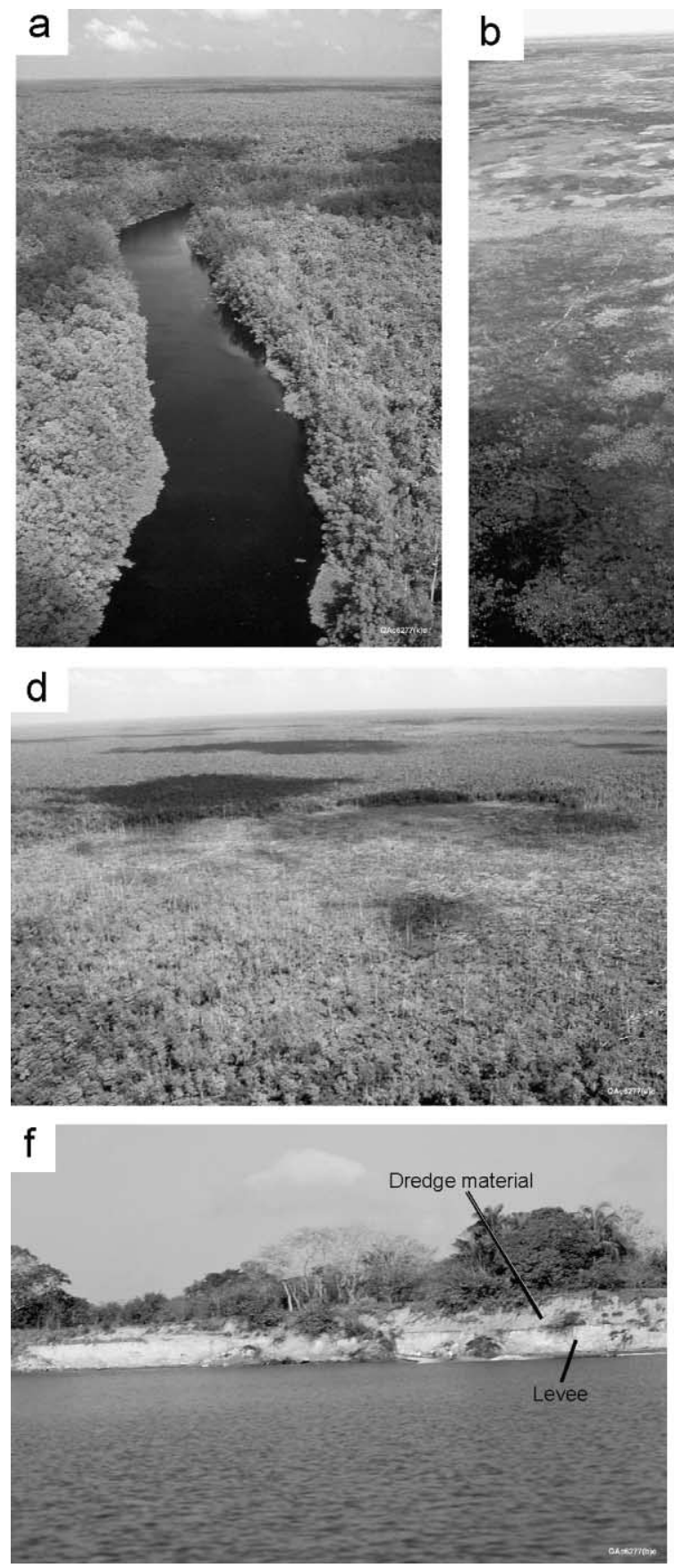

b
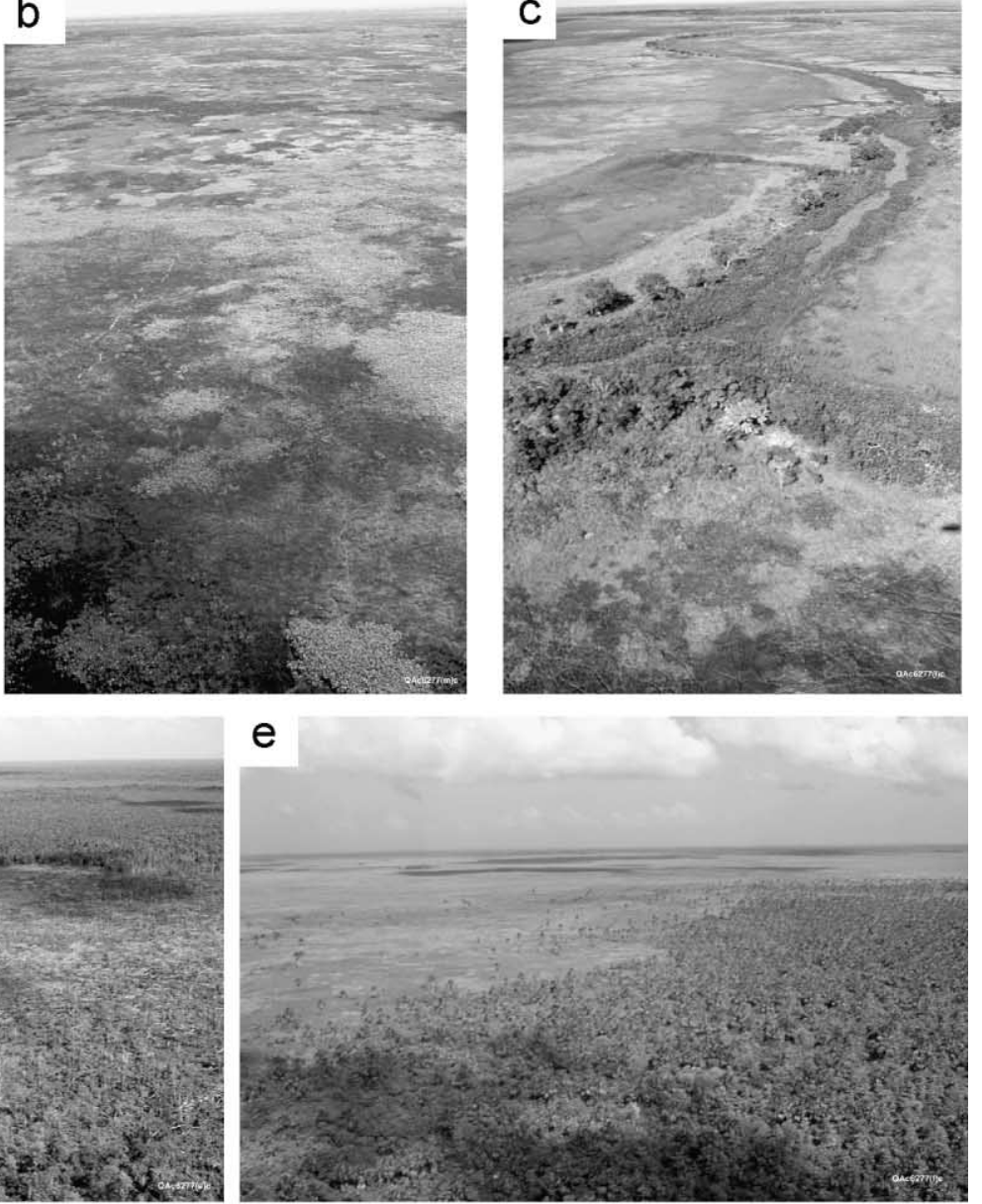

g

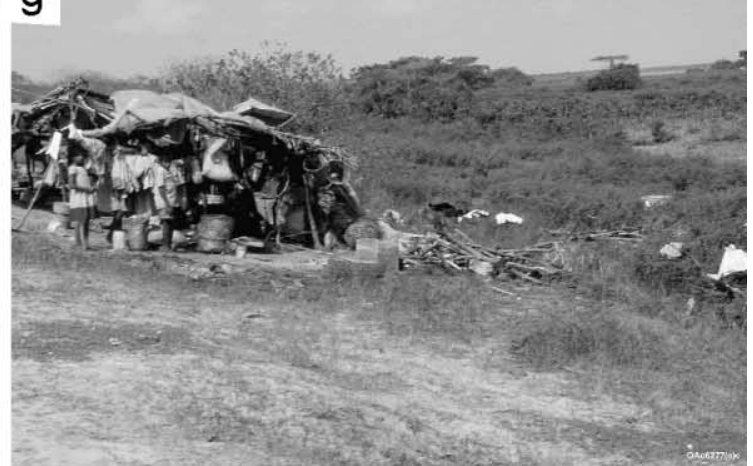



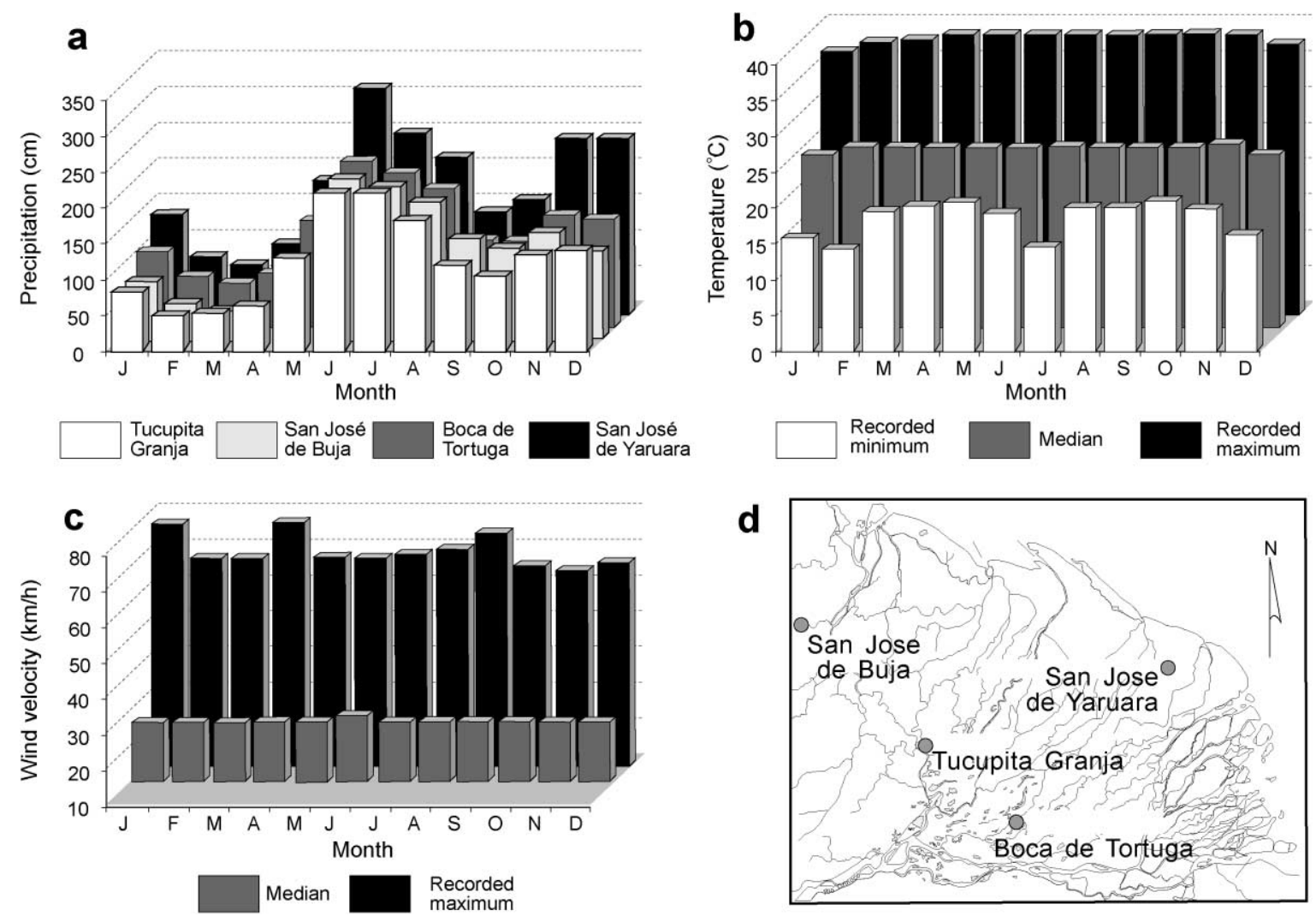

Fig. 14. Climatic conditions across the Orinoco Delta. (a) Rainfall: records generally from 1970 to 1990, but in some cases longer. (b) Temperature at Tucupita, 1970-1995. (c) Wind velocity at Tucupita, 1970-1995. A wind rose is presented in Fig. 15. (d) Locations of meteorology stations. Data from FUNINDES USB (1998).

middle, and 0 to $3.3 \mathrm{~mm} \mathrm{year}^{-1}$ for the lower delta plain (Warne et al., 1999, Table 16). Sediments have nearly filled available accommodation space in the upper delta plain, and lateral erosion/sedimentation processes predominate. In the middle and lower delta, where subsidence rates are higher, vertical accretion processes predominate, and broad perennially inun- dated and/or saturated interdistributary basins have developed.

These interdistributary basins are slightly elevated along the borders and generally flat in the center. Relief between basin edge and center is typically no more than $1.5 \mathrm{~m}$. These vast interdistributary basins (Fig. 13a-e) are seasonally to perennially flooded and

Fig. 13. Photographs of the Orinoco delta plain. (a) Middle reach of Caño Cocuinita, a typical blackwater distributary channel in the northwestern delta (October 1998). (b) Herbaceous interdistributary basin supporting a variety of plant communities, middle delta plain (March 1998). (c) Herbaceous interdistributary basin supporting a variety of plant communities, upper delta plain. Note forested levee along Caño Macareo in distance (March 1998). (d) Widespread tree mortality in interdistributary basin, middle delta plain. Tree mortality is induced by increased water depths and/or duration of inundation, and demonstrates the dynamic relationship between delta-plain geomorphology, hydrology, and ecology (March 1998). (e) Interdistributary basin showing the transition from a forested (mixed palm and deciduous) to herbaceous wetland, middle delta plain (March 1998). (f) Levee bank along upper Caño Macareo. This reach contains the best-developed levees in the delta. The uppermost layer along the bank is dredge material. Caño Macareo, however, is currently not being dredged (March 1998). (g) Basinward side of levee in the upper delta plain. Levee has been cleared for human activity (March 1998). 


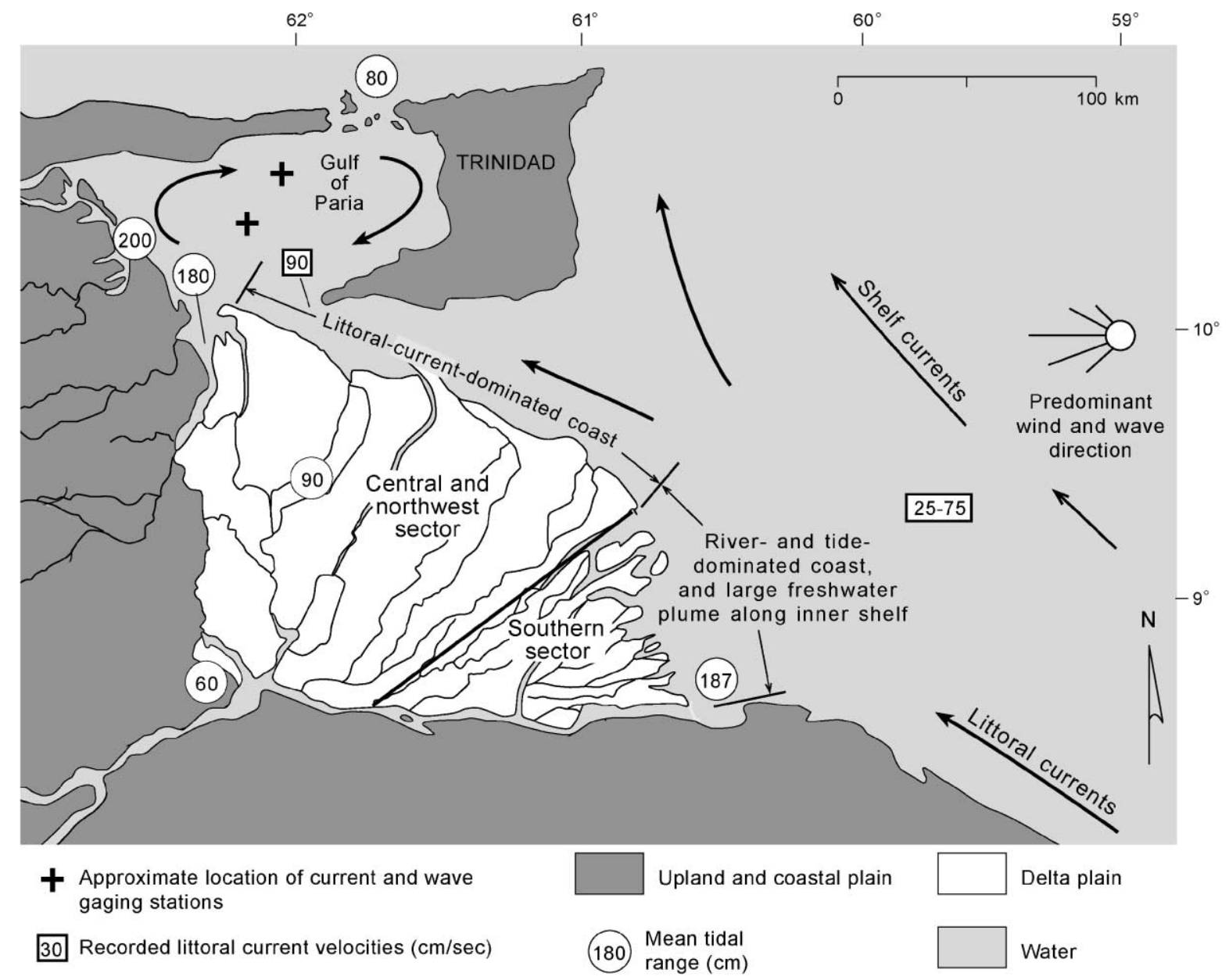

Fig. 15. Summary of marine hydrodynamics along the Orinoco Delta coast. Data sources include Van Andel and Postma (1954), Nota (1958), Koldewijn (1958), Van Andel (1967), Herrera et al. (1981), INTEVEP (1981), Herrera and Masciangioli (1984), Geohidra Consultores (1997a,b), and ENSR Venezuela (1998).

are typically underlain by mud in the upper and southeastern delta and peat in the central and northwestern delta (Fig. 11). Interdistributary basins vary from densely forested to herbaceous with all manner of gradation between; floristic composition largely depends on proximity to caños, duration of flooding, degree of salinity, and fresh water input from precipitation.

The delta-plain (interdistributary basin) substrate is composed primarily of silt, mud, and peat (Fig. 11).

Fig. 16. Sediment dynamics along Orinoco Delta coast. (a) Composite Landsat image of coast, processed using Bands 4 , 2, and 7 and then converted to graytone. The northwestern half (Punta Pescadores area) was acquired in April 1989, and the southeast half (Boca Grande area) was acquired in November 1987. Cloud cover precluded the use of a single date. The mud plume seaward of Boca Grande appears to be moving orthogonal to the coast. Mixing of fresh and marine water masses is apparent in the Boca Araguao area. Processes that cause the sharp boundary between high and low sediment-concentration seawater are currently not understood. (b) Schematic cross-section showing the buoyant suspension layer at Boca Grande. 

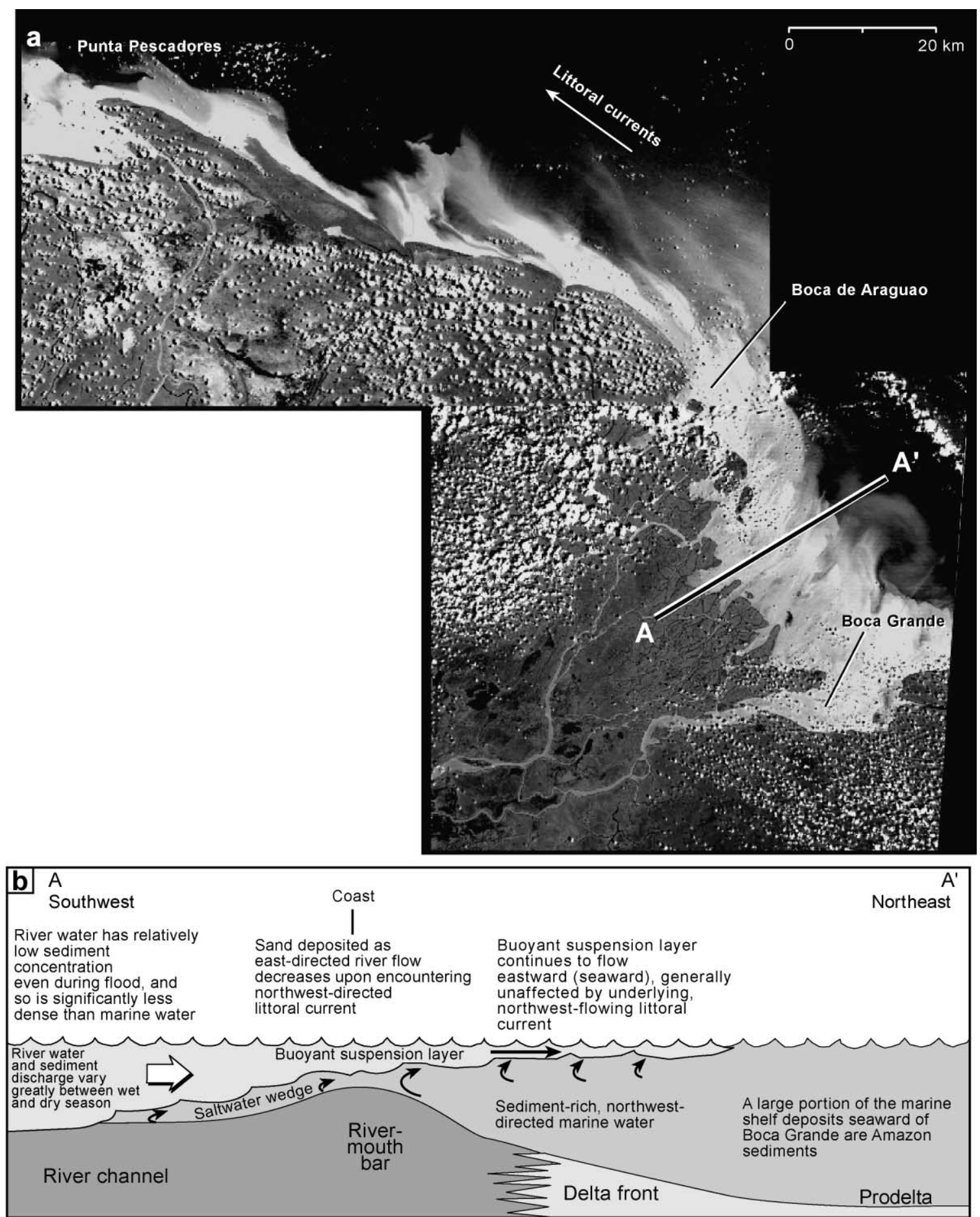
Channel bottoms of the major distributaries are composed of well sorted, fine to medium sand (Warne et al., 1999, Table 9), and broad, sandy river-mouth bars occur along the coast (Fig. 1b). Levee sediment composition ranges from clay to fine sand, but primarily consists of silt (Lorente, 1990).

Distributary channel hydrodynamics are generally controlled by river discharge during the wet season (May through September) and by tidal oscillations during the dry season. An extensive network of coastparallel channels hydraulically links the principal distributary channels (Fig. 1). Several major caños are deflected to the northwest in the coastal region under the influence of the suspended-sediment rich, northwest-flowing Guayana Current and associated mudcape development. The major caños are bordered by levees that form distinct topographic features in the upper delta plain (Fig. 13f,g) but gradually diminish in height toward the coast. The levees are typically the highest features in the delta plain, but are regularly overtopped during flood stage, and serve to retain water in the interdistributary basins as flood stage recedes. Human activity is typically concentrated on these elevated, relatively well-drained landforms (Fig. 13g). Two major distributaries (Grande and Manamo) broaden near the coast, transforming to estuaries.

Direct rainfall is a major environmental factor in the Orinoco Delta, because it is a major source of fresh water for the vast interdistributary basins. Rainfall varies across the delta, ranging from about 1500 $\mathrm{mm}$ near the delta apex to about $2600 \mathrm{~mm}$ per year near the coast (Figs. 2c and 14a). Although there is a pronounced dry season, rainfall typically exceeds 100 $\mathrm{mm}$ per month throughout the year in the lower delta and is an important source of fresh water during low river stage. The river and delta are situated just south of the migration pathway of hurricanes that track from the central Atlantic into the Caribbean region. Therefore, hurricanes are not a major influence on river and delta processes, but they occasionally (recurrence interval of about 10 years) induce moderately high winds (Fig. 14), heavy rains, and high-energy waves in the delta region (FUNINDES, 1998; ENSR Venezuela, 1998; US Weather Bureau, 1999) As expected in a tropical environment removed from the track of major tropical disturbances, rainfall is common but generally not intense; when rainfall is intense, it is of short duration.

The Orinoco coast is much like the Guiana coast to the south, with alternating estuaries and rounded promontories (Figs. 1 and 8a). The estuaries reflect the combined influence of tidal and river processes, whereas the mudcapes reflect the influence of the strong, northwest-directed littoral currents (Herrera and Masciangioli, 1984). Tidal amplitudes along the Orinoco coast generally range from 1.2 to $2.6 \mathrm{~m}$ (Fig. 15 and Table 1). Tides affect the entire delta plain, and tidal amplitudes are 0.7 to $1.1 \mathrm{~m}$ in the central delta and about $0.6 \mathrm{~m}$ at the delta apex (Eisma et al., 1978; FUNINDES USB, 1998). Wave power along the Orinoco Delta coast is relatively low because incoming waves are attenuated by the wide, shallow Orinoco shelf and by muddy substrates near the coast (Geohidra Consultores, 1997a,b; ENSR Venezuela, 1998).

The strong, northwest-flowing Guayana Current acts as a barrier to keep the turbid Orinoco waters on the shelf (Fig. 16a), so that suspended sediment concentrations in surface waters on the inner shelf are tens or hundreds of times greater than those of the outer shelf (Emel'yanov and Kharin, 1974). The Guayana Current flows northwestward more or less unimpeded from the Amazon to the Orinoco Delta, where it is disrupted by Trinidad, and consequently subdivides (Fig. 15). One branch flows eastward and northward, passes between Trinidad and Tobago, and is dispersed in the Caribbean Sea. The other branch of the Guayana Current flows into the Gulf of Paria through the Boca de Serpientes (Fig. 15). As the

Fig. 17. Orinoco Delta coastal features. (a) Erosional coastline with weak beach development and dead mangrove in the surf zone. Landward erosion has resulted in a thin belt of coastal mangrove. As is common along the Orinoco coast, mangroves are backed by extensive herbaceous marshes (March 1998). (b) Erosional to static shoreline, as indicated by modest sand beach development, straight profile, and broad stand of mangrove landward of coast (March 1998). (c) Beach ridges (cheniers) near the mouth of Boca Araguao. These relatively well-drained, sandy areas are cleared (by burning) to graze livestock (March 1998). (d) Mud flats along the Atlantic coast at low tide. Note distinct break in slope along seaward edge of mud flat (November 1998). (e) Mudflat in the Boca Araguao area, recently colonized by mangrove (March 1998). 
(a)

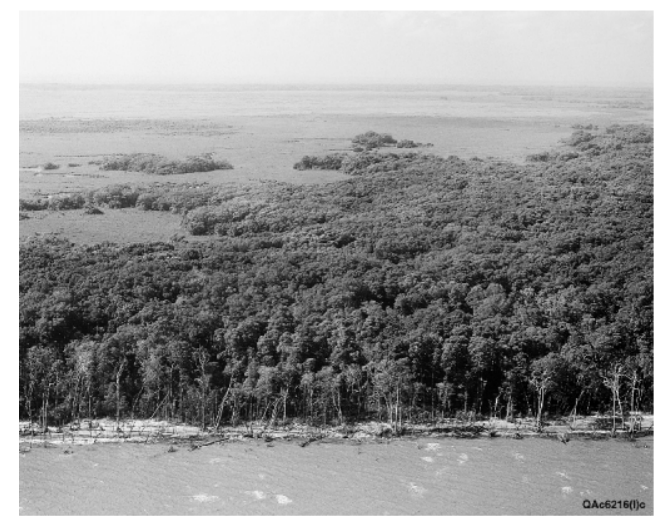

(c)

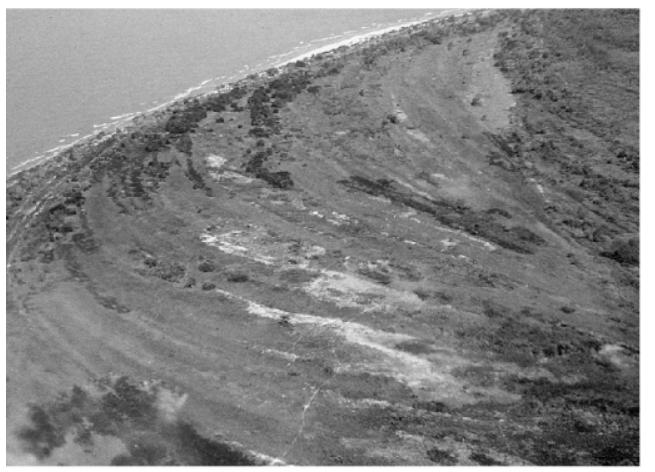

(e)

(b)

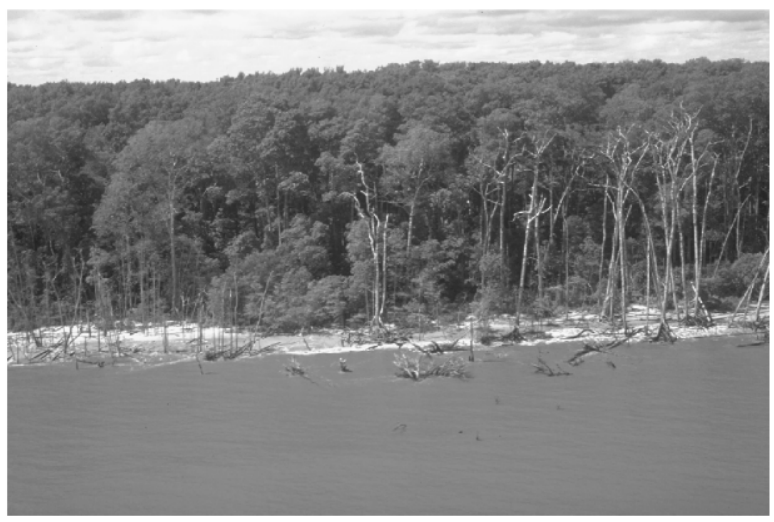

(d)

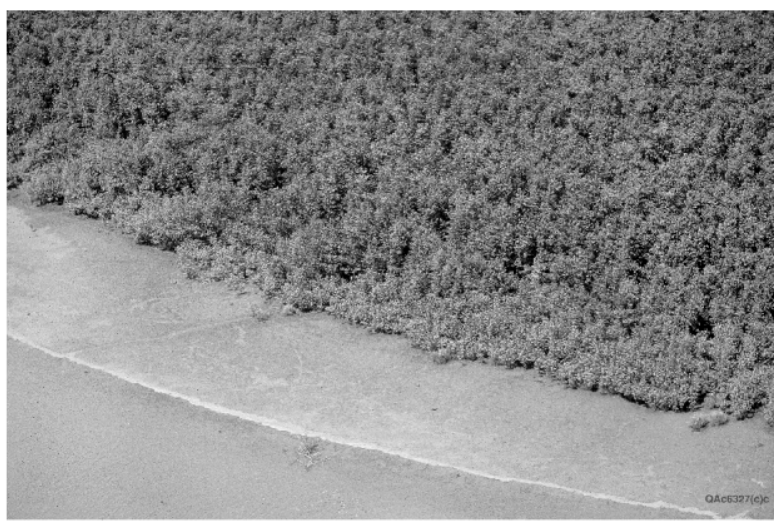

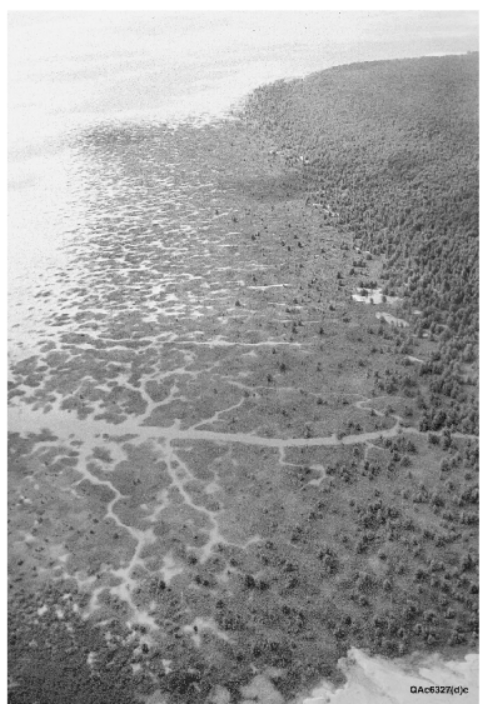


branch of the Guayana Current flows toward Boca de Serpientes, it is constricted, which causes velocity to increase. Currents within the Gulf of Paria generally flow in a clockwise fashion, although a complex system of residual estuarine and tidal currents exists
(Van Andel, 1967). Nearshore marine current measurements along Punta Pescadores demonstrate that flow direction oscillates between dominantly southeastward along the coast and seaward as tides are falling and northwestward along the coast and land-

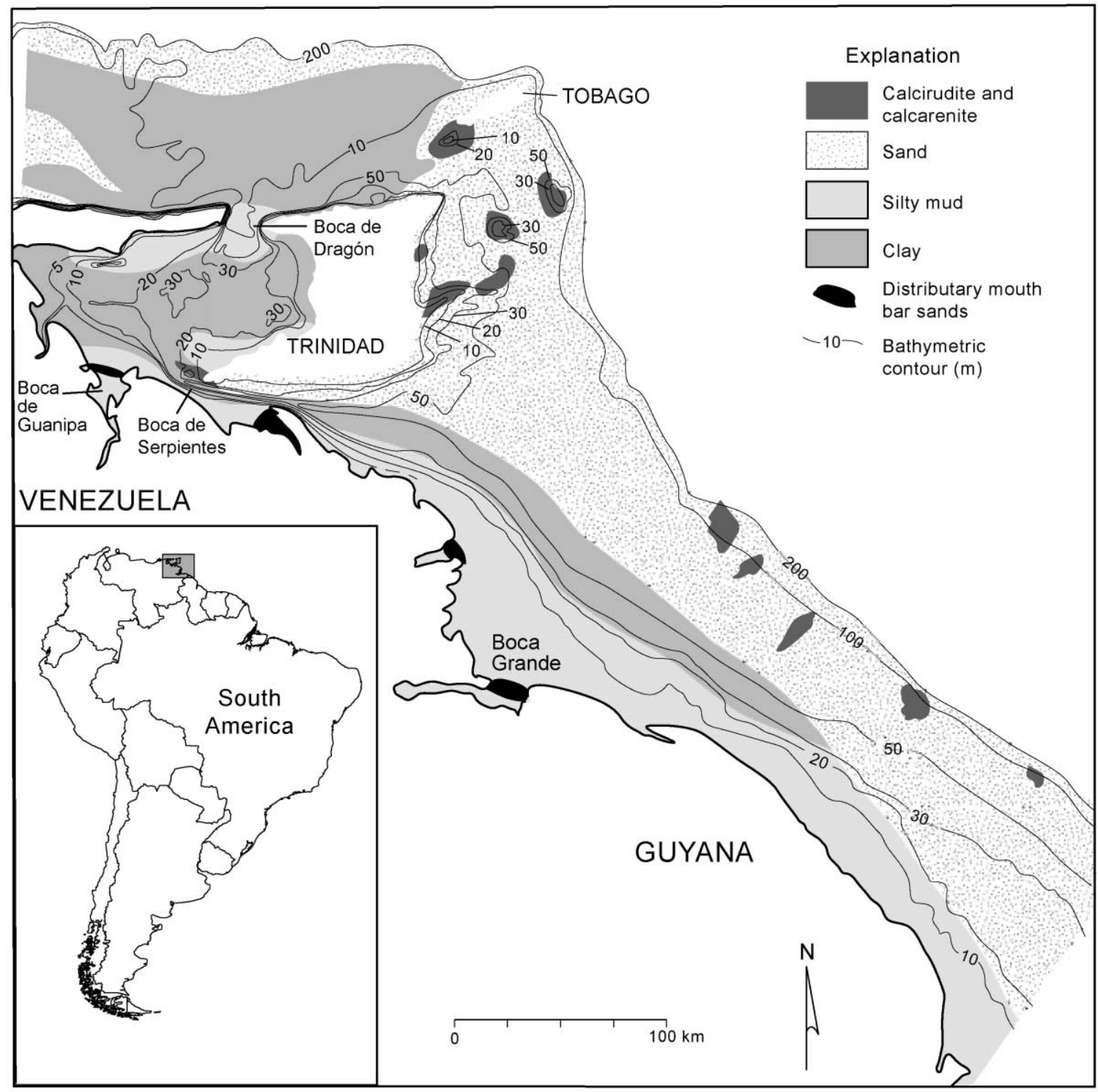

Fig. 18. Sediment distribution and bathymetry across the Orinoco shelf. Compiled from Van Andel and Postma (1954), Nota (1958), Koldewijn (1958), McClelland Engineers (1979). The clay substrate seaward of the Orinoco coast defines the extent of the submarine delta. The distribution of the clay and silty mud substrate indicate that the Gulf of Paria and the south Caribbean Sea near Boca Dragón are major depositional sites for Orinoco sediment. The distribution of clays along the shelf and in the Gulf of Paria emphasizes the importance of littoral currents in the dispersion of Orinoco and Amazon sediments. 
ward as tides rise (Herrera et al., 1981; Geohidra Consultores, 1997b).

Like other modern deltas and the adjacent Guiana coast, the Orinoco shoreline has erosional and nondepositional as well as accretional segments. Erosional shorelines tend to be straight to concave (seaward) in map view; they typically have a small scarp at the shoreface; mature mangrove forests abut the shoreface; and the mangroves are being actively undermined by the encroaching waves, causing the mangroves to collapse into the surf (Fig. 17a). Historical aerial photographs indicate that the coast has eroded landward as much as $2 \mathrm{~km}$ in some areas between Boca Cocuina and Pedernales (Wagner and Pfefferkorn, 1995). Nondepositional shorelines are typically straight, and mangrove forests abut the shoreface but are not collapsing into the surf; in places, small silty, sandy beaches develop (Fig. 17b).

Accretional coastlines commonly occur along the borders of estuaries as well as along the Atlantic coast. Accretional shorelines typically have mud flats that are up to 2-km wide during low tide (Fig. 17d). Mudflats are extremely low-gradient and tend to accrete laterally along the break in slope at the seaward edge of the flats (Fig. 17d). The very shallow water conditions along the mudflats and the soft but cohesive mudflat surface strongly attenuates incoming wave energy, promoting vertical accretion along the landward portions of the mudflats. Colonization by mangroves along the landward portion of the intertidal zone (Fig. 17e) further promotes vertical accretion. Downdrift of river mouths, sandy beaches develop locally. Sandy beaches are particularly well developed in the Boca Araguao area and likely represent nascent chenier ridges (Fig. 17c).

The Orinoco shelf is a broad, low-gradient $(0.02 \%$ to $0.5 \%$ ) feature (Butenko and Barbot, 1979). The Orinoco delta-front and prodelta deposits are as thick as $70 \mathrm{~m}$ and form a rather narrow belt oriented parallel to the Atlantic shoreline, extending only about 40 to $60 \mathrm{~km}$ seaward to the coast (Fig. 18). Seaward of the prodelta deposits, the shelf and slope are relict, submerged, sandy coastal plains that developed during Pleistocene sea-level lowstands (McClelland Engineers, 1979). The limited seaward extent of the delta front and prodelta deposits (relative to their thickness) and their uneven distribution along the coast (Warne et al., 1999, fig. 41) suggest that northwest-flowing littoral and associated bottom currents limit delta progradation along the central and northwestern delta.

The Gulf of Paria is a semi-enclosed, tectonic basin located seaward and adjacent to the northwest Orinoco Delta (Figs. 12 and 15). The gulf receives and retains a significant portion of Orinoco sediment (Fig. 18) that is discharged from Caño Manamo (prior to construction of Volcán Dam) and is transported northeastward through Boca de Serpientes by littoral currents (Van Andel, 1967). The two rather narrow inlet/ outlets, Boca de Serpientes in the south and Boca de Dragón on the north, largely control water and sediment dynamics in the gulf. Boca de Serpientes is the narrower (as little as $15 \mathrm{~km}$ ) and shallower (a thalweg depth as little as $33 \mathrm{~m}$ ) than Boca de Dragón of the two inlet/outlets (Van Andel and Postma, 1954). Interaction of neotectonism, delta progradation, and sea-level change altered water circulation through Boca de Serpientes during the Holocene, thereby profoundly influencing Orinoco water and sediment dynamics along the Atlantic coast and shelf and within the Gulf of Paria (Warne et al., 1999, in press). Currently, the constriction at Boca de Serpientes accelerates longshore currents (Fig. 15), which intensifies littoral and bottom current processes along the central delta coast and shelf.

\section{Discussion}

Surface-water and sediment dynamics (including rates of inflow, throughflow, and outflow as well as timing, frequency, and duration of inundation and saturation of the substrate) are controlling factors in delta ecosystem composition, structure, and long-term stability. Regional evaluation and interpretation of river and coastal systems, and their interaction with the delta plain, coast, and shelf, are essential for identifying major processes controlling delta evolution and the influence of these processes on delta water and sediment dynamics, and ecosystem integrity.

The Orinoco River basin maintains a very high discharge/drainage basin area ratio (Table 1), largely because of high rainfall, the impermeable, crystalline Guayana Shield, and perennially high groundwater levels of the Llanos region. This high ratio promotes large seasonal fluctuations in river stage and dis- 
charge. Large changes in seasonal discharge are also promoted by the location of the Orinoco basin in the northern portion of the ITCZ; at a regional scale, seasonal rainfall intensity varies uniformly across the drainage basin so that peak (and low) discharges occur simultaneously in all major tributaries. Orinoco River water discharge induces almost complete inundation of the delta during the flood season (June to October), and maintains perennial inundation of about $80 \%$ of the delta plain. Diurnal tides, which influence the entire delta plain (Fig. 15), promote ecosystem variability by creating a spectrum of fresh-to-saline surface water conditions in the middle and lower delta. Large rainfall volumes vary across the delta (Fig. 14a), and contribute to hydrologic, geochemical and ecosystem variability.

Differential subsidence toward the coast promotes marine influence and vertical accretion processes in the lower delta (Warne et al., 1999). We infer that a secondary component of differential subsidence in the southern delta is a major determinant in the position of Río Grande and has promoted formation of the large estuary at Boca Grande and Boca Araguao (Nota, 1958). Neotectonic features have been identified within the delta (Kidwell and Hunt, 1958; Pees et al., 1968; Warne et al., 1999), and are related to activity along the adjacent South Caribbean Plate Boundary Zone (Fig. 12).

Approximately half of the $1.5 \times 10^{8}$ tons year ${ }^{-1}$ of Orinoco River sediment is deposited on the delta plain (Meade, 1994). We infer that river flood discharge is capable of transporting sand bedload within the principal distributary channels. Suspended load is mostly limited to silt and clay, and once overbank discharge begins, the transport capacity of the floodwater rapidly diminishes away from the channel such that floodwaters are capable of maintaining only clay in suspension. Because peak river sediment discharge is not coincident with peak water discharge, terrigenous sediments tend not to be transported to basin centers but rather to form broad mounds around the basin perimeters that further inhibits influx of terrigenous sediments to the central basin areas. Moreover, river sediment concentrations are relatively low, even during flooding. As a result, many of the interdistributary basins in the middle and lower delta plain are sediment-starved and sites of peat development. Because Río Grande transports more than $80 \%$ of the sediment through the delta, the northwestern delta is especially sediment-starved and supports extensive peat basins (Figs. 10 and 11). The uneven distribution of river water and sediment discharge across the delta plain (Colonnello, 1998; Bracho et al., 1998) has been amplified by construction of Volcán Dam on upper Caño Manamo (Fig. 10).

River flood discharge helps form distributary channels, and diurnal tides perform the majority of geomorphic work within the Orinoco Delta channel network (Geohidra Consultores, 1997a,b; FUNINDES USB, 1998). Differences in distributary channel geometry and resistance to flow result in significant differences in the timing of diurnal tide oscillations among channels. These out-of-phase tidal oscillations result in substantial differences in water surface elevations between adjacent channels, which induce development of the cross-channel network of caños (Fig. 1). The channel network is dynamic, and channel avulsion, hydraulic isolation, and channel infilling are common processes across the delta (Fig. 13c). Preliminary analysis of radiocarbon-dated sedimentary cores corroborate Van Andel's (1967) assertion that major distributaries, such as Manamo and Cocuina, are no more than 1000 years old (Warne et al., 1999). Historical aerial photographs of the Boca de Guanipa area demonstrate significant expansion of estuarine islands (i.e., infilling of the estuary) during the past 45 years (Warne et al., 1999, in press).

Approximately $50 \%$ of the sediment deposited along the Orinoco coast is derived from the Amazon River, $1600 \mathrm{~km}$ to the south (Fig. 19c). The Orinoco is not unique among world deltas in receiving major sediment input from adjacent river systems; a significant portion of the Holocene-age sediment deposited along the Changjiang (Yangtze) Delta coast and shelf was supplied by littoral current transport of sediment derived from the Huanghe (Yellow) River when the

Fig. 19. Summary of major river and coastal processes influencing water and sediment dynamics in northeastern South America. (a) General characteristics; see text for further discussion. (b) Characteristics of the Orinoco Delta region. (c) Sediment budget for northeastern South America coastal region (modified from Meade, 1994). 


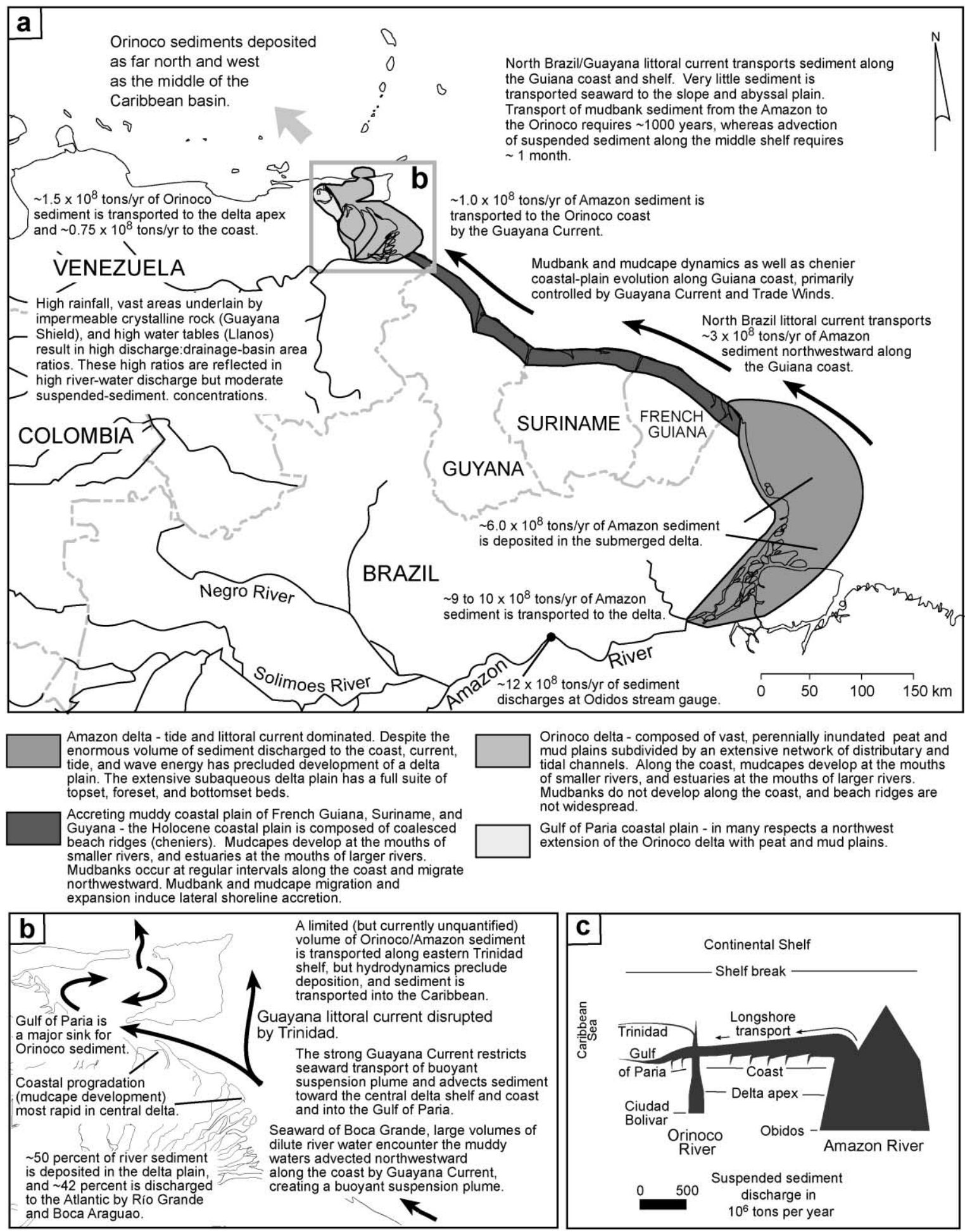


Huanghe Delta was further south than at present (Chen, 1998). The Amazon River is an important sediment source, not only in terms of volume, but also in terms of the timing of sediment supply (by longshore transport); Amazon sediment input may be more constant than the seasonal Orinoco sediment discharge. Although, the intensity of Guayana Current flow may vary seasonally (Colin and Bourles, 1992), the timing and nature of sediment input from along the Guiana Coast remains poorly understood. It is evident that littoral marine waters flowing from the Guiana coast into Boca Grande contain high concentrations and large volumes of suspended Amazon mud (Danielo, 1976; Eisma et al., 1991).

More than $80 \%$ of Orinoco discharge to the coast is through Boca Grande (Fig. 10), and suspended sediment concentrations of Orinoco River water are moderate, even during flood season. We infer that a buoyant, fresh water plume develops as the Orinoco River water encounters the dense, muddy, marine waters (Fig. 16b). Development of fresh water plumes at the mouths of delta distributaries is common (Orton and Reading, 1993; Nemec, 1995). We infer that the buoyant suspension (or hypopycnal) layer is especially well developed along the Orinoco coast because of the large density difference in the dilute river and sediment-rich marine water. The density contrast is maintained as the Guayana Current imports large volumes of dense, muddy littoral marine waters and the Río Grande continuously supplies large volumes of dilute fresh water.

Fig. 16a provides evidence for the Orinoco buoyant suspension layer in that the sediment plumes directly seaward of Boca Grande are orthogonal to the coast, indicating the surface-water flow regime is controlled primarily by river flow and is detached from the regional, northwest-flowing, shallow shelf regime. Toward Boca Araguao, the sediment plumes progressively assume a more northeasterly orientation, indicating mixing with the littoral current cell.

Van Andel and Postma (1954) determined that during the wet season, water masses in Boca de Guanipa and Pedernales (prior to Volcán Dam) separated into two layers: an upper fresh to brackish water layer that flows seaward and a lower saline wedge. They postulated that a buoyant fresh water layer develops and saline bottom currents penetrate into the estuaries during wet season discharge. They inferred that the buoyant suspension layer disintegrates during dry season discharge. We propose that in Río Grande, with its large, year-round, fresh water discharge volume, the buoyant suspension layer is maintained for much of the year.

Largely on the basis of remote sensing analysis (e.g., Fig. 16a), we infer that the buoyant Orinoco River plume is transported northwestward along the shelf and coast by the Guayana Current and eventually mixes with marine waters (Van Andel and Postma, 1954; Nota, 1958; Koldewijn, 1958). We infer that Orinoco and Amazon sediments mix just northwest of Boca Grande and (1) a substantial portion of the sediment is transported landward by waves and tides and deposited along the Orinoco coast and shelf (McClelland Engineers, 1979); (2) a substantial portion is transported through Boca de Serpientes and into the Gulf of Paria (Fugro Gulf, 1979; INTEVEP, 1981); and (3) a small portion is transported northeastward along the south coast of Trinidad and then northward along the eastern margin of Trinidad (Koldewijn, 1958) (Figs. 15 and 19).

Although tidal mudflats and mudcapes are principal features along the Orinoco coast, we did not observe fluid mud layers or mudbanks. Danielo (1976) recognized mudbanks along the coast of Corocoro Island (mudcape) just southeast of Boca Grande but did not document them along the Orinoco Delta coast. Moreover, the extensive mudflats that characterize the Guiana coast are less developed along the Orinoco coast.

We propose that discharge of large volumes of dilute fresh water at Boca Grande disperses fluid muds, and thereby inhibits development of mudbanks along the Orinoco coast. We infer that disruption and fragmentation of the Guayana Current along the Orinoco shelf also inhibits development of fluid muds and associated mudbanks. Although fluid muds do not appear to be prevalent along the Orinoco coast, we observed mud-rich waters at several sites along the coast (Figs. 16a and 17d) (cf. Monente, 1989/1990). We also recognize that fluid muds are present in the bottom of the dredged navigation channel in Boca Grande, as described by Martin et al. (1976) and summarized by Eisma et al. (1978), but we suspect that these muds are a local response to the repeated overboard dis- 
posal of dredge material along the margins of the channel.

The relatively broad subaqueous delta seaward of Boca Grande (Figs. 1 and 18) may be the result of deposition of Amazon mud and silt as the Guayana Current flow is impeded by water flowing from Boca Grande. We suspect that subsidence rates are relatively high in this area, which provides accommodation space for the submarine delta deposits. We infer that development of the buoyant suspension plume along Boca Grande inhibits development of a delta plain but promotes development of the submarine delta. Field observations and analysis of satellite imagery indicate that the central delta coast is prograding rapidly (Figs. 1, 16a and 19). We infer that progressive constriction of Boca de Serpientes (as the Orinoco Delta has prograded eastward) has concentrated and accelerated littoral current flow and increasingly inhibited delta-plain progradation along the northwestern delta, resulting in a relatively steep gradient seaward of the northwest delta coast (Figs. 1 and 18).

The Gulf of Paria, on the other hand, has been a major depositional area for the Orinoco Delta. Subsurface data demonstrate that up to $70 \mathrm{~m}$ of Holocene sediment have been deposited in the basin (Van Andel and Postma, 1954; Fugro Gulf, 1979; INTEVEP, 1981; Warne et al., 1999, in press). Water and sediment regulation at Volcán Dam has reduced fresh water and sediment influx into the Gulf of Paria (Fig. 10). Milliman et al. (1982) estimated that approximately $2 \%$ of the Orinoco/Amazon sediment passes through Boca de Dragón and is deposited on the continental shelf and upper slope north of the Paria Peninsula (Figs. 1, 18 and $19 \mathrm{a}-\mathrm{c}$ ). Bowles and Fleischer (1985) reported Orinoco sediment as far north as the central Caribbean basin.

\section{Conclusion}

The Orinoco Delta is an integral part of the Orinoco drainage basin as well as a prograding coastal plain system that extends from the Amazon Delta to the northern Gulf of Paria (Fig. 19a). In order to identify and evaluate the fundamental sources and controls of water and sediment flow into, through, and out of the Orinoco Delta (Fig. 19), we have summarized major river, coastal plain, and shallow marine systems of northeastern South America. The regional analysis highlights the following as major factors controlling Orinoco Delta ecosystem composition, structure, and distribution:

- the location of the delta within an active foredeep basin adjacent to a major plate tectonic boundary (Fig. 12);

- the variability of direct rainfall across the delta plain (Fig. 14);

- the pronounced annual flood discharge peak (Fig. 4);

- the uneven distribution of water and sediment discharge across the delta (Fig. 10);

- the discharge of large volumes of water with low sediment concentrations through the Río Grande and Araguao distributaries;

- the water and sediment dynamics associated with the Guayana littoral current along the northeastern South American coast (Fig. 19a);

- the inflow of large volumes of Amazon sediment to the Orinoco coast (Fig 19c);

- the development of a buoyant suspension layer seaward of Boca Grande (Fig. 16);

- the disruption of the Guayana Current by Trinidad, Boca de Serpientes, and Gulf of Paria (Fig. 15 and 19b); and

- the constriction at Boca de Serpientes in the northwestern delta (Figs. 1, 18 and 19b).

Many inferences presented in this paper are based on our reconnaissance field observations, remote sensing imagery, limited available data, and by analogy with other, better-studied river, delta, and coastal systems. There have been very few systematic monitoring surveys of the Orinoco delta plain, coast, shelf, and Gulf of Paria. Despite the shortcomings of the available database, this preliminary but comprehensive analysis serves to summarize what is currently understood about the Orinoco Delta system. This study can be used to identify critical data and research areas that will contribute to the development of comprehensive, reliable sedimentologic and hydrologic models needed to protect this valuable natural resource as human activity in the Orinoco Delta and northeastern South America increases. 


\section{Acknowledgements}

Petróleos de Venezuela (PDVSA) provided the financial support for this research. We are particularly grateful to Drs. German Febres and Heriberto Echezuria, who have served the project as Technical Coordinators for PDVSA/DAO. Drs. Rodulfo Prieto, Freddy Chiquito, and Jose Ruiz (PDVSA) also provided invaluable information and logistical support. We thank Drs. José Méndez-Baamonde and Carlos Yanes of Universidad Central de Venezuela for their participation in the delta field excursions. Field work would not be possible without the logistical support of Mr. Abelardo Lara and his boat crews and Dr. Freddy Rudulfo (PDVSA-Palmaven) in Tucupita. The Director of the Bureau of Economic Geology, The University of Texas at Austin (BEG), authorized the publication.

We are grateful to Drs. Mead Allison, Zhongyuan Chen, Sharon Fitzgerald, Sandra Cooper, and Avijit Gupta for thoughtful reviews of the manuscript, which significantly enhanced the quality of the manuscript. We are grateful to William Bergquist, John T. Ames, Patricia Alfano, Jana S. Robinson, Joel L. Lardon, and David M. Stephens (BEG) for generating the figures. We thank Susann Doenges and Lana Dieterich for editing, and Susan Lloyd (BEG) for word processing.

\section{References}

Allison, M.A., Nittrouer, C.A., 1998. Identifying accretionary mud shorefaces in the geologic record: insights from the modern Amazon dispersal system. In: Schieber, J., Zimmerle, W., Sethi, P. (Eds.), Shales and Mudstones: I.E. Schweizerbart'sche Verlagsbuchhandlung (Nägele u. Obermiller), Stuttgart, Germany, pp. $147-161$.

Allison, M.A., Nittrouer, C.A., Faria Jr., L.E.C., 1995. Rates and mechanisms of shoreface progradation and retreat downdrift of the Amazon river mouth. Mar. Geol. 125, 373-392.

Allison, M.A., Lee, M.T., Ogston, A.S., Aller, R.C., 2000. Origin of Amazon mudbanks along northeastern coast of South America. Mar. Geol. 163, 241-256.

Beltrán, C., 1993. Mapa neotectónico de Venezuela. FUNVISIS Departmento de Ciencias de la Tierra, Caracas, scale 1:2,000,000. 1 sheet.

Bowles, F.A., Fleischer, P., 1985. Orinoco and Amazon River sediment input to the eastern Caribbean basin. Mar. Geol. 68, 53-72.

Bracho, H., Gerendas, G., Arreaza, M., Sanchez, E., De Santis, P., Balladares, C., 1998. Diagnóstico ambiental en Delta Amacuro.
In: López-Sánchez, J.L., Saavedra-Cuadra, I.I., Dubois-Martínez, M. (Eds.), El Río Orinoco Aprovechamiento Sustentable: Primeras Jornadas Venezolanas de Investigación Sobre el Río Orinoco. Instituto de Mecánica de Fluidos, Facultad de Ingeniería, Universidad Central de Venezuela, Carolas, pp. 24-35.

Brinkman, R., Pons, L.J., 1968. A pedo-geomorphological classification and map of the Holocene sediments in the coastal plain of the three Guianas. Soil Survey Papers, vol. 4. Soil Survey Institute, Wageningen, The Netherlands, $41 \mathrm{pp}$.

Butenko, J., Barbot, J.P., 1979. Geological hazards related to offshore drilling and construction in the Orinoco River Delta of Venezuela. Offshore Technology Conference 11 Proceedings, v. 1, paper 3395, Houston, pp. 323-329.

Carbón, J., Schubert, C., 1994. Late Cenozoic history of the eastern Llanos of Venezuela; geomorphology and stratigraphy of the Mesa Formation. In: Iriondo, M. (Ed.), Quaternary of South America. Quaternary International, 21, 91-100.

Carvalho, N.O., da Cunha, S.B., 1998. Estimativa da carga sólida do rio Amazonas e seus principal tributários para a foz e oceano: uma retrospectiva. Agua Rev. 6 (10), 44-58.

Case, J.E., Holcombe, T.L., 1980. Geologic-tectonic map of the Caribbean region. U.S. Geological Survey Miscellaneous Investigation Series Map I-1100, scale 1:2,500,000. 3 sheets.

Chen, X., 1998. Changjian (Yangtze) River Delta, China. J. Coastal Res. 14, 838-858.

Coleman, J.M., 1981. Deltas: Processes of Deposition and Models for Exploration Burgess Publishing, Boston, MA, 124 pp.

Colin, C., Bourles, B., 1992. Western boundary currents in front of French Guiana. In: Prost, M.T. (Ed.), Évolution des Littoraux de Guyane et de la Zone Caribe Méridonale Pedant le Quaternaire. Editions de l'ORSTOM Institut Français de Recherche Scientifique pour la Développement en Coopération, Paris, pp. 73-91.

Colonnello, G., 1998. El impacto ambiental causado por el represamiento del Caño Manamo: Cambios en la vegetación riparina, un caso en estudio. In: López-Sánchez, J.L., Saavedra-Cuadra, I.I., Dubois-Martínez, M. (Eds.), El Río Orinoco Aprovechamiento Sustentable: Primeras Jornadas Venezolanas de Investigación Sobre el Río Orinoco. Instituto de Mecánica de Fluidos, Facultad de Ingeniería, Universidad Central de Venezuela, Caracas, pp. 36-54.

Corporación Venezolana de Guayana (CVG), 1991a. Informe de avance NC-20-11 y 12. Clima, Geología, Geomorfología. Tomo I. Gerencia de Proyectos Especiales, Proyecto Inventario de los Recursos Naturales de la Región Guayana. CVG, Caracas, $1-$ 222.

Corporación Venezolana de Guayana, 1991b. Informe de avance NC-20-11 y 12. Suelos, Vegetación. Tomo II. Gerencia de Proyectos Especiales, Proyecto Inventario de los Recursos Naturales de la Región Guayana. CVG, Caracas, 223-621.

Corporación Venezolana de Guayana, 1991c. Informe de avance NC-20-15. Clima, Geología, Geomorfología. Tomo I. Gerencia de Proyectos Especiales, Proyecto Inventario de los Recursos Naturales de la Región Guayana. CVG, Caracas, 1-474.

Corporación Venezolana de Guayana, 1991d. Informe de avance NC-20-15. Suelos, Vegetación. Tomo II. Gerencia de Proyectos Especiales, Proyecto Inventario de los Recursos Naturales de la Región Guayana. CVG, Caracas, 477-1088. 
Corporación Venezolana de Guayana, 1991e. Informe de avance NC-20-16. Clima, Geología, Geomorfología. Tomo I. Gerencia de Proyectos Especiales, Proyecto Inventario de los Recursos Naturales de la Región Guayana. CVG, Caracas, 313 pp.

Corporación Venezolana de Guayana, 1991f. Informe de avance NC-20-16. Suelos, Vegetación. Tomo II. Gerencia de Proyectos Especiales, Proyecto Inventario de los Recursos Naturales de la Región Guayana. CVG, Caracas, 315-817.

Daniel, J.R.K., 1988. Sea defence strategies and their impact on a coast subject to a cyclic pattern of erosion and accretion. Ocean Shoreline Manage. 11, 159-175.

Danielo, A., 1976. Photointerprétation, sedimentation et géochronologie dans le delta de l'Orenoque. Rev. Geogr. Phys. Geol. Dyn. 18 (5), 407-414.

DeLaune, R.D., Pezeshki, S.R., 1994. The influence of subsidence and saltwater intrusion on coastal marsh stability; Louisiana Gulf Coast, USA. J. Coastal Res. 12, 77-89.

Di Croce, J., Bally, A.W., Vail, P., 1999. Sequence stratigraphy of the Eastern Venezuela Basin. In: Mann, P. (Ed.) (Series Editor: Hsu, K.J.), Caribbean Basins. Sedimentary Basins of the World. Elsevier, Amsterdam, pp. 417-474.

Djuwansah, M., Delaune, M., Marius, C., 1992. Sedimentologie des formations Holocenes de la Guyane Français. In: Prost, M.T. (Ed.), Évolution des Littoraux de Guyane et de la Zone Caribe Méridonale Pedant le Quaternaire. Editions de l'ORSTOM Institut Français de Recherche Scientifique pour la Développement en Coopération, Paris, pp. 133-149.

Dunne, T., Mertes, L.A.K., Meade, R.H., Richey, J.E., 1998. Exchanges of sediment between the floodplain and channel of the Amazon River in Brazil. Geol. Soc. Am. Bull. 110, 450467.

Eisma, D., vander Gaast, S.J., Martin, J.M., Thomas, A.J., 1978. Suspended matter and bottom deposits of the Orinoco Delta: turbidity, mineralogy and elementary composition. Neth. J. Sea Res. 12 (2), 224-251.

Eisma, D., Augustinus, P.G.E.F., Alexander, C., 1991. Recent and subrecent changes in the dispersal of Amazon mud. Neth. J. Sea Res. 28 (3), 181-192.

Emel'yanov, E.M., Kharin, G.S, 1974. Sedimentation in the Guiana and North American basins in relation to sediment discharge of the Amazon and Orinoco Rivers. Litol. Polezn. Iskop. 2, $22-$ 25.

ENSR Venezuela, 1998. Estudio de impacto ambiental, Proyecto I, Perforación exploratoria 1998, Bloque Golfo de Paria Este. Unpublished Report for the Ministry of the Environment and Renewable Natural Resources of Venezuela. Gulf of Paria East Operating, Caracas, Venezuela, 458 pp.

Franzinelli, E, 1992. Evolution of the geomorphology of the coast of the State of Para, Brazil. In: Prost, M.T. (Ed.), Évolution des Littoraux de Guyane et de la zone Caribe Méridonale Pedant le Quaternaire. Editions de l'ORSTOM Institut Français de Recherche Scientifique pour la Développement en Coopération, Paris, pp. 203-231.

Fugro Gulf, 1979. Geotechnical investigation Golfo de Paria, offshore Venezuela. Unpublished Report to Instituto Tecnológico Venezolano del Petróleo (INTEVEP), Report no. 75-005-5, Caracas, Venezuela, $69 \mathrm{pp}$.
FUNINDES USB, 1998. Estudio de impacto ambiental proyecto de perforación exploratoria Bloque Delta Centro, Fase I. Unpublished Report for Delta Centro Operating, Caracas, Venezuela, 102 pp.

Geohidra Consultores, C.A., 1997a. Estudio de impacto ambiental del proyecto Uno de perforación exploratoria del bloque Guarapiche. Unpublished Report for Agencia Operadora Guarapiche (AOGSA), project DA96037, version 1. Caracas, Venezuela, variously paginated.

Geohidra Consultores, C.A., 1997b. Estudio de impacto ambiental proyecto perforación exploratoria área prioridad Este bloque Punta Pescador-AMOCO. Unpublished Report for AMOCO. Report 96017-E4, Caracas, Venezuala, variously paginated.

Gibbs, A., Barron, C.N., 1983. The Guiana Shield reviewed. Episodes $2,7-14$.

Hamilton, S.K., Lewis Jr., W.M. 1990. Basin morphology in relation to chemical and ecological characteristics on lakes on the Orinoco River floodplain, Venezuela. Arch. Hydrobiol. 119 (4), $393-425$.

Herrera, L.E., Masciangioli, P., 1984. Características de las corrientes frente al delta del Orinoco, sector occidental del Océano Atlántico. Rev. Tec. INTEVEP 4 (2), 133-144.

Herrera, L., Febres, G., Avila, R., 1981. Las mareas en aguas venezolanas y su amplificación en la región del Delta del Orinoco. Acta Cient. Venez. 32, 299-308.

INTEVEP, 1981. Diseño Conceptual de Plataformas para el Norte de Paria y el Golfo de Paria. PDVSA, Caracas, Venezuela, 52 pp.

Johnsson, M.J., Stallard, R.F., Lundberg, N., 1991. Controls on the composition of fluvial sands from a tropical weathering environment; sands of the Orinoco River drainage basin, Venezuela and Colombia. Geol. Soc. Am. Bull. 103 (12), 1622-1647.

Kidwell, A.L., Hunt, J.M., 1958. Migration of oil in recent sediments of Pedernales, Venezuela. Habitat of Oil. American Association of Petroleum Geologists Symposium, pp. 790-817.

Kineke, G.C., Sternberg, R.W., 1995. Distribution of fluid muds on the Amazon continental shelf. Int. J. Mar. Geol. Geochem., Geophys. $125,193-233$.

Koldewijn, B.W., 1958. Guiana shelf region. Marine geology, sedimentation, South America: Sediments of the Paria-Trinidad shelf. Amsterdam University. Fys. Geog. Lab., Pub. 1, 109 pp.

Kuehl, S.A., De Master, D.J., Nittrouer, C.A., 1986. Nature of sediment accumulation on the Amazon Continental Shelf. Cont. Shelf Res. 6 (1-2), 209-225.

Kuehl, S.A., Levy, B.M., Moore, W.S., Allison, M.A., 1997. Subaqueous delta of the Ganges-Brahmaputra river system. Mar. Geol. 144, 81-96.

Leonard, R., 1983. Geology and hydrocarbon accumulations, Columbus Basin, Offshore Trinidad. Am. Assoc. Pet. Geol. Bull. 67 (7), 1081-1093.

Lewis Jr., W.M., Hamilton, S.K., Saunders III, J.F. 1995. Rivers of Northern South America. In: Cushing, C.E., Cummins, K.W., Minshall, G.W. (Eds.), Ecosystems of the World 22. River and Stream Ecosystems. Elsevier, Amsterdam, pp. 219-256.

Lorente, M.A., 1990. Textural characteristics of organic matter in several subenvironnments of the Orinoco upper delta. In: Cleef, A.M., Van Geel, B., Hooghiemstra, H., Roeleveld, W., Wijmstra, T.A. (Eds.), Palynology, a key to climatic and geographic 
change, a tribute to Thomas van der Hammen. Geologie en Mijnbouw 69, 3, pp. 263-278.

Martin, J.M., Thomas, A.J., Perez-Nieto, H., 1976. Àpplication des mesures de radioactivité naturelle a l'étude de la dynamique sédimentaire dans le delta de l'Orénoque. Publication Conférence Géologique des Caraïbes, 7th, Pointe-à-Pitre Guadeloupe, 1974, pp. 555-565.

McClelland Engineers, 1979. Interpretation and assessment of shallow geologic and geotechnical conditions, Orinoco regional survey areas, offshore Orinoco Delta, Venezuela. Unpublished Report to Instituto Tecnológico Venezolano del Petróleo, Job no. 13051, Caracas, Venezuela, 55 pp.

Meade, R.H., 1994. Suspended sediments of the modern Amazon and Orinoco rivers. In: Iriondo, M. (Ed.), Quaternary of South America, Quaternary International 21, 29-39.

Meade, R.H., 1996. River-sediment inputs to major deltas. In: Milliman, J.D., Haq, B.U. (Eds.), Sea-level Rise and Coastal Subsidence. Kluwer Academic Publishers, Dordrecht, Netherlands, pp. $63-85$.

Meade, R.H., Nordin Jr., C.F., Pérez-Hernández, D., Mejía-B., A., Pérez-Godoy, J.M., 1983. Sediment and water discharge in Río Orinoco, Venezuela and Colombia. Proceedings of the Second International Symposium on River Sedimentation, 11-16 October. Water Resources and Electric Power Press, Nanjing, China, pp. $1134-1144$.

Meade, R.H., Dunne, T., Richey, J.E., Santos, U., De, M., Salati, E., 1985. Storage and remobilization of suspended sediment in the lower Amazon River of Brazil. Science 228, 488-490.

Meade, R.H., Weibezahn, F.H., Lewis, W.M., Pérez-Hernández, D., 1990. Suspended-sediment budget for the Orinoco River. In: Weibezahn, F.H., Alvarez, H., Lewis, Jr., W.M. (Eds.), El Río Orinoco como Ecosistema. Impresos Rubel, Caracas, Venezuela, pp. $55-79$.

Meade, R.H., Rayol, J.M., Conceição, S.C., Natividade, J.R.G., 1991. Backwater effects in the Amazon river basin of Brazil. Environ. Geol. Water Sci. 18 (2), 105-114.

Milliman, J.D., Meade, R.H., 1983. World-wide delivery of river sediments to the oceans. J. Geol. 91, 1-22.

Milliman, J.D., Butenko, J., Barbot, J.P., Hedberg, J., 1982. Depositional patterns of modern Orinoco/Amazon muds on the northern Venezuelan shelf. J. Mar. Res. 40 (3), 643-657.

Monente, J.A., 1989/1990. Materia en suspensión transportada por el Río Orinoco. Memoir, Sociedad de Ciencias Naturales La Salle IL/L 133-134, 5-13.

Nemec, W., 1995. The dynamics of deltaic suspension plumes. In: Oti, M.N., Postma, G. (Eds.), Geology of Deltas. A.A. Balkema, Rotterdam, pp. 31-93.

Nittrouer, C.A., Curtin, T.B., DeMaster, D.J., 1986a. Concentration and flux of suspended sediment on the Amazon continental shelf. Cont. Shelf Res. 6 (1-2), 151-174.

Nittrouer, C.A., Kuehl, S.A., DeMaster, D.J., Kowsman, R.O., 1986b. The deltaic nature of Amazon shelf sedimentation. Geol. Soc. Am. Bull. 97, 444-458.

Nittrouer, C.A., Kuehl, S.A., Sternberg, R.W., Figueredo, A.G., Faria, L.E.C., 1995. An introduction to the geological significance of sediment transport and accumulation on the Amazon continental shelf. Mar. Geol. 125, 177-192.
Nordin Jr., C.F., Perez-Hernandez, D. 1989. Sand waves, bars, and wind-blown sands of the Río Orinoco, Venezuela and Colombia. U. S. Geol. Surv. Water-Supply Pap. 2326A, 74 pp.

Nordin, C.F., Mejía, A., Delgado, C., 1994. Sediment studies of the Orinoco River, Venezuela. In: Schumm, S.A., Winkley, B.R. (Eds.), The variability of large rivers. ASCE Press, New York, pp. $243-265$.

Nota, D.J.G., 1958. Sediments of the western Guiana Shelf. Reports of the Orinoco Shelf Expedition, v. II. Meded. Landbowhogeschool te Wageningen, Nederlands 58, 2, 1-98.

Orton, G.J., Reading, H.G., 1993. Variability of deltaic processes in terms of sediment supply, with particular emphasis on grain size. Sedimentology 40, 475-512.

Pees, S.T., Banks, L.M., Segovia, A., 1968. Petroleum geology of the Territorio Federal Delta Amacuro, Venezuela. Bol. Inf., Asoc. Venez. Geol., Min. Pet. 11 (4), 93-122.

Pérez-Hernández, D., López, J.L., 1998. Algunos aspectos relevantes de la hidrología del Río Orinoco. In: López-Sánchez, J.L., Saavedra-Cuadra, I.I., Dubois-Martínez, M. (Eds.), El Río Orinoco Aprovechamiento Sustentable: Primeras Jornadas Venezolanas de Investigación sobre el Río Orinoco. Instituto de Mecánica de Fluidos, Facultad de Ingeniería, Universidad Central de Venezuela, Caracas, pp. 89-98.

Pimentel-de-Bellizzia, N., 1984. Mapa Geológico estructural de Venezuela: República de Venezuela Ministerio de Energía y Minas Dirección General Sectorial de Minas y Geología, scale 1:2,500,000. 1 sheet.

Prost, M.-T., 1992. Sedimentation cotiere et formation de cheniers en Guyane: la zone de Cayenne. In: Prost, M.T. (Ed.), Évolution des littoraux de Guyane et de la zone Caribe méridonale pedant le Quaternaire. Editions de l'ORSTOM Institut Français de Recherche Scientifique pour la Développement en Coopération, Paris, pp. 397-415.

Ramírez, A.J., Mogollón, J.L., Bifano, C., Yanes, C.E., 1992. Water, dissolved solids and suspended sediment discharge to Venezuelan coastline. In: Prost, M.T. (Ed.), Évolution des littoraux de Guyane et de la zone Carïbe méridonale pedant 1 e Quaternaire. Editions de l'ORSTOM Institut Français de Recherche Scientifique pour la Développement en Coopération, Paris, pp. 437456.

Rine, J.M., Ginsburg, R.N., 1985. Depositional facies of a mud shoreface in Suriname, South America - a mud analogue to sandy, shallow marine deposits. J. Sediment. Petrol. 55 (5), 633-652.

Robertson, P., Burke, K., 1989. Evolution of southern Caribbean Plate boundary, vicinity of Trinidad and Tobago. Am. Assoc. Pet. Geol. Bull. 73 (4), 490-509.

Sommerfield, C.K., Nittrouer, C.A., Figuiredo, A.G., 1995. Stratigraphic evidence of changes in Amazon shelf sedimentation during the late Holocene. Int. J. Mar. Geol., Geochem., Geophys. $125,351-371$.

Stallard, R.F., 1985. River chemistry, geology, geomorphology, and soils in the Amazon and Orinoco basins. In: Drever, J.I. (Ed.), The Chemistry of Weathering. D. Reidel, Dordrecht, Holland, pp. $293-316$.

Stallard, R.F., 1987. Cross-channel mixing and its effects on sedimentation in the Orinoco River. Water Resour. Res. 23, 1977-1986.

Stallard, R.F., Koehnken, L., Johnsson, M.J., 1991. Weathering 
processes and composition of inorganic material transported through the Orinoco River system, Venezuela and Colombia. Geoderma 51, 133-165.

Stanley, D.J., Warne, A.G., 1994. Worldwide initiation of Holocene marine deltas by deceleration of sea-level rise. Science 265, $232-288$.

Stanley, D.J., Warne, A.G., 1998. Nile delta in its destruction phase. J. Coastal Res. 14, 794-825.

US Weather Bureau, National Huricane Center, 1999. Past hurricane history. http \\www.nhc.noaa.gov/pastall.html, accessed July, 1999.

Van Andel, Tj. H., 1967. The Orinoco Delta. J. Sediment. Petrol. 37 (2), 297-310.

Van Andel, Tj. H., Postma, H., 1954. Recent sediments of the Gulf of Paria. Reports of the Orinoco shelf expedition, v. I. Kon. Ned. Akad. Weten. Verh. 20, 5, 1-245.

Vann, J.H., 1969. Landforms, vegetation, and sea level change along the Guiana coast of South America. State University College at Buffalo Technical Report no. 3. Buffalo, NY., 128 pp.

Volker, A., Adriaanse, M., Allersma, W., Blumenthal, K.P., Boekelman, R.H., van Duivendijk, J., van Ellen, W.F.T., Jagroop, C.D., Jelgersma, D., van Kippen, P.C., Leentvaar, P., Luijten, P., Mulder, M.A.A., van Moorsel, G.G.N.M., Oerlemans, J., Oude Essink, G.H.P., de Ridder, N.E., Schiereck, G.J., Shahin, M.M.A., van der Tuin, H., de Vries, W.S., 1993. Hydrology and Water Management of Deltaic Areas: Centre for Civil Engineering Research and Codes Report 93-5. A.A. Balkema, Rotterdam, Netherlands, $312 \mathrm{pp}$.
Wagner, T., Pfefferkorn, H.W., 1995. Tropical peat occurrences in the Orinoco Delta: Preliminary assessment and comparison to carboniferous coal deposits. Prace Panstwowego Instytutu Geologiznego CLVII, Proccedings of the XIII International Congress on the Carboniferous and Permian, pp. 161-168.

Warne, A.G., Aslan, A., White, W.A., Gibeaut, J.C., Tremblay, T.A., Smyth, R.C., Guevara, E.H., Gutierrez, R., Hovorka, S.D., Raney, J.A., 1999. Final Report Year Two: Geoenvironmental characterization of the Delta del Orinoco: Report to Petróleos de Venezuela. The University of Texas at Austin Bureau of Economic Geology, 327 pp.

Warne, A.G., Guevara, E.H., Aslan, A., in press. Late Quaternary evolution of the Orinoco Delta, Venezuela. J. Coastal Res.

Welcomme, R.L., 1979. Fisheries Ecology of Floodplain Rivers. Longman, London, $317 \mathrm{pp}$.

Wells, J.T., Coleman, J.M., 1981a. Periodic mudflat progradation, northeastern coast of South America: a hypothesis. J. Sediment. Petrol. 51 (4), 1069-1075.

Wells, J.T., Coleman, J.M., 1981b. Physical processes and finegrained sediment dynamics, coast of Suriname, South America. J. Sediment. Petrol. 51 (4), 1053-1068.

Wong, Th.E., Krook, L., Zonneveld, J.I.S., 1998. Investigations in the coastal plain and offshore area of Suriname. In: Wong, Th.E., de Vletter, D.R., Krook, L., Zonneveld, J.I.S., van Loon, A.J. (Eds.), The History of Earth Sciences in Suriname. Royal Netherlands Academy of Arts and Sciences Netherlands Institute of Applied Geoscience, Amsterdam, pp. 73-100. 